\title{
34. HYDROTHERMAL ALTERATION OF A SECTION OF UPPER OCEANIC CRUST IN THE EASTERN EQUATORIAL PACIFIC: A SYNTHESIS OF RESULTS FROM SITE 504 (DSDP LEGS 69, 70, AND 83, AND ODP LEGS 111, 137, 140, AND 148) ${ }^{1}$
}

\author{
Jeffrey C. Alt, ${ }^{2}$ Christine Laverne, ${ }^{3}$ David A. Vanko, ${ }^{4}$ Paola Tartarotti, ${ }^{5}$ Damon A.H. Teagle, ${ }^{2}$ Wolfgang Bach,${ }^{6,7}$ \\ Evelyn Zuleger, ${ }^{8}$ Jörg Erzinger, ${ }^{6}$ José Honnorez, ${ }^{9}$ Philippe A. Pezard, ${ }^{3,10}$ Keir Becker, ${ }^{11}$ \\ Matthew H. Salisbury, ${ }^{12}$ and Roy H. Wilkens ${ }^{13}$
}

\begin{abstract}
Mineralogical, chemical, and isotopic results from seven drilling legs that visited DSDP/ODP Hole 504B over 14 years are compiled here to present an integrated view of hydrothermal alteration of oceanic crust at Site 504. Hole 504B reaches to 2111 mbsf, through $274.5 \mathrm{~m}$ sediment, $571.5 \mathrm{~m}$ of volcanic rocks, a $209 \mathrm{~m}$ transition zone, and $1050 \mathrm{~m}$ into a sheeted dike complex. The volcanic section was altered through a series of processes involving interaction with seawater at low temperatures, with the effects of cold, oxidizing seawater decreasing downward. These processes and their effects on the volcanic section are generally similar to those in other oceanic upper crustal sections.

The transition zone and upper dikes were altered in a subsurface mixing zone, where hydrothermal fluids upwelling through the dikes mixed with cooler seawater circulating in the overlying more permeable volcanic rocks. Alteration of the transition zone and upper dikes (down to $1500 \mathrm{mbsf}$ ) occurred in a series of stages, reflecting the thermal and chemical evolution of the hydrothermal system from (1) early chlorite, actinolite, albite-oligoclase, and titanite, to (2) quartz, epidote and sulfides, to (3) anhydrite, and finally to (4) zeolites and local calcite. The maximum temperature estimated for the first two stages is $350^{\circ}-$ $380^{\circ} \mathrm{C}$, and the inferred mineral assemblages for these early stages are typical of the greenschist facies.

The lower dikes (1500-2111 mbsf) underwent an early, high-temperature $\left(\geq 400^{\circ} \mathrm{C}\right)$ alteration stage, resulting in the formation of hornblende and calcic secondary plagioclase, consistent with reactions inferred to occur in deep subsurface reaction zones, where hydrothermal vent fluids acquire their final compositions. Much of the subsequent reactions produced greenschist assemblages at $\sim 300^{\circ}-400^{\circ} \mathrm{C}$. The lower dikes have lost metals and sulfur and are a source of these elements to hydrothermal vent fluids and seafloor sulfide deposits. The lower dikes underwent subsequent alteration stages similar to the upper dikes, with rare epidote + quartz veins recording the presence of upwelling hydrothermal fluids, and limited late off-axis effects (zeolites and prehnite). Anhydrites in the lower dikes indicate more reacted fluid compositions than in the upper dikes.

Alteration of the sheeted dikes from Hole 504B is heterogeneous, with recrystallization controlled by fracturing and access of fluids. Defining the position of the seismic Layer $2 / 3$ transition depends upon the scale of observation, but the change at Site 504 occurs within the sheeted dikes and is correlated with progressive changes in porosity and hydrothermal alteration. However, we still do not know the nature of the transition from sheeted dikes to gabbros in in situ ocean crust, or the nature of the inferred fault at the base of Hole 504B and its role in fluid flow and alteration.
\end{abstract}

\section{INTRODUCTION}

'Alt, J.C., Kinoshita, H., Stokking, L.B., and Michael, P.J. (Eds.), 1996. Proc. ODP, Sci. Results, 148: College Station, TX (Ocean Drilling Program).

${ }^{2}$ Department of Geological Sciences, 2534 C.C. Little Building, The University of Michigan, Ann Arbor, MI 48109-1063, U.S.A. Alt: jalt@umich.edu; Teagle teagle@umich.edu

'Laboratoire de Pétrologie Magmatique, URA CNRS 1277, Faculté des Sciences et Techniques de Saint-Jérôme, Avenue Escadrille Normandie-Niemen, F-13397 Marseille Cedex 20, France. pezard@ imtmerl.imt-mrs.fr

${ }^{4}$ Department of Geology, Georgia State University, Atlanta, GA 30303-3083, U.S.A. geodav@gsusgil.gsu.edu

'Dipartimento di Geologia, Paleontologia e Geofisica, Università di Padova, Via Giotto 1, 35137 Padova, Italy, tar@epidote.dmp.unipd.it

${ }^{6}$ GeoForschungsZentrum Potsdam, Projektbereich 4.2, Telegrafenberg A50, D-14473 Potsdam, Federal Republic of Germany. Bach: wbach@gfz-potsdam.de; Erzinger:erz@gfz-potsdam.de

'Present address: Universităt Potsdam. Institut für Geowissenschaften, Postfach 601553, D-14415 Potsdam, Federal Republic of Germany.

${ }^{8}$ GEOMAR Forschungszentrum für Marine Geowissenschaften, Wischhofstrasse

1-3, Gebaude 5, D-24148 Kiel, Federal Republic of Germany. ezuleger@geomar.de

'Institut de Geologie, Universite Louis Pasteur, 1 rue Blessig, 67084 Strasbourg Cedex, France. honnorez@illite.u-strasbg.fr

${ }^{10}$ Laboratoire de Mesures en Forage, Institut Méditerranéen de Technologie, Technopôle de Château-Gombert, F-13451 Marseille Cedex 20, France.

"Division of Marine Geology and Geophysics, Rosenstiel School of Marine and Atmospheric Sciences, 4600 Rickenbacker Causeway, University of Miami, Miami, FL 33149-1098, U.S.A. kbecker@rsmas.miami.edu

${ }^{12}$ Geological Survey of Canada Atlantic, Bedford Institute of Oceanography, Dartmouth, P.O. Box 1006, Nova Scotia, B2Y 4A2, Canada. matts@agc.bio.ns.ca

${ }^{13}$ Hawaii Institute of Geophysics and Planetology, School of Ocean and Earth Science and Technology, University of Hawaii, Honolulu, HI 96822, U.S.A. wilkens@soest.hawaii.edu
Hole 504B is the deepest scientific drill hole in the oceans, penetrating to $2111 \mathrm{mbsf}$ ( $1836.5 \mathrm{~m}$ sub-basement) over the course of seven Ocean Drilling Program (ODP) and Deep Sea Drilling Project (DSDP) legs since 1979 (DSDP Legs 69, 70, and 83, and ODP Legs 111, 137, 140, and 148; Cann et al., 1983; Anderson, Honnorez, Becker, et al., 1985; Becker, Sakai, et al., 1988; Becker, Foss, et al., 1992; Dick, Erzinger, Stokking, et al., 1992; Alt, Kinoshita, Stokking, et al., 1993). The hole was also visited during Leg 92 in 1983 for downhole logging and to sample borehole fluids (Leinen, Rea, et al., 1986). It is the only hole to penetrate through the volcanic section into the underlying sheeted dike complex, and the site has become a reference section for the petrology, geochemistry, hydrothermal alteration, and magnetic and physical properties of the upper oceanic crust (Anderson, Honnorez, et al., 1982; Becker et al., 1989). Previous drilling results from the site (Dick, Erzinger, Stokking, et al., 1992) and seismic evidence (Becker, Sakai, et al., 1988; Collins et al., 1989; Mutter, 1992) suggested that the bottom of the hole lay within the lower portion of the sheeted dike complex, close to the seismic Layer 2/Layer 3 boundary. It has been thought that this transition coincides with the change downward from sheeted dikes to underlying gabbros, or that it is a metamorphic boundary within gabbros or sheeted dikes (e.g., Fox et al., 1973; Christensen and Salisbury, 1975). The transition from sheeted dikes to gabbros has been observed by submersible in tectonic exposures of both Atlantic and Pa- 
cific ocean crust (Auzende et al., 1990; Francheteau et al., 1990), but has never been observed in situ in undisturbed ocean crust, and its relation to the Layer 2/Layer 3 boundary was unproven before Leg 148. Leg 148 returned to Hole 504B in the eastern Pacific to deepen the hole with the main goals of penetrating into oceanic gabbros and determining the nature of the transition from Layer 2 to Layer 3.

During Leg 148, Hole 504B was deepened by $110.6 \mathrm{~m}$, to a total depth of 2111 mbsf. Further penetration was prevented when the drill string became stuck in a fault zone at this depth within sheeted dikes (Alt, Kinoshita, Stokking, et al., 1993). This paper summarizes alteration effects throughout the Hole 504B core, but focuses on a mineralogical and geochemical comparison between upper and lower dikes ( 1000-1500 mbsf and 1500-2111 mbsf, respectively). These exhibit significant differences that have implications for the structure of submarine hydrothermal systems and for chemical and isotopic exchange between seawater and the crust. Also in this paper, alteration effects are correlated with other properties of the crust, in particular with porosity and fracturing as determined by electrical resistivity logs, and with sonic velocities from core measurements, borehole logs, and the vertical seismic profile experiment in order to address the question of the nature of the Layer $2 / 3$ transition in oceanic crust.

\section{SITE 504}

Hole 504B is located in 6-Ma crust, $200 \mathrm{~km}$ south of the Costa Rica Rift in the eastern equatorial Pacific (Fig. 1; see recent tectonic setting review by Dick, Erzinger, Stokking, et al., 1992). The Costa Rica Rift spreads asymmetrically at intermediate rates of $3.6 \mathrm{~cm} / \mathrm{yr}$ to the south and $3.0 \mathrm{~cm} / \mathrm{yr}$ to the north (Hey et al., 1977). The basement relief south of the Costa Rica Rift results from the presence of normal faults parallel to the rift axis, which produce south-tilted grabens separated by ridges 1 to $2 \mathrm{~km}$ wide (Langseth et al., 1983; Hobart et al., 1985). Hole 504B is located in an area where the measured heat flow falls close to the theoretical conductive cooling curve for ocean crust (Langseth et al., 1983). The high sedimentation rate $(50 \mathrm{~m} / \mathrm{m} . \mathrm{y}$.) has resulted in a thick sediment cover that effectively seals the relatively smooth basement surface (about 100-200 m relief) from open communication with seawater. Such sealing of the crust occurs throughout the oceans, but generally at much greater crustal ages (up to 20 80 m.y.; Stein and Stein, 1994). Thus, Site 504 was sealed off from free access by seawater relatively early, and this may have led to a somewhat greater geothermal gradient at the site than elsewhere in the crust. Detailed heat-flow measurements around Site 504, however, indicate continuing subdued convection around Site 504 (Langseth et al., 1988), and chemical gradients in sediment pore waters reveal that fluids advect through the sediment (Langseth et al., 1988). Modeling of the heat-flow data suggests that convection is mainly restricted to the upper few hundred meters of basement, and that basement topography controls the geometry of circulation (Fisher et al., 1990, 1994).

\section{Lithostratigraphy of Hole 504B}

Hole 504B penetrates $274.5 \mathrm{~m}$ of sediments (siliceous oozes, chert, limestone, and chalk); a 571.5-m volcanic section (Fig. 2), comprised of pillow and massive flows, breccias, and possible local dikes or sills in the lower half of the section; a 209-m transition zone of pillow basalts and dikes; and $1056 \mathrm{~m}$ of a sheeted dike complex. Core recovery averaged $29.8 \%$ in the volcanic section, $25.3 \%$ in the transition zone, and $13.7 \%$ in the sheeted dikes. The rocks recovered from Hole 504B are aphyric to highly phyric tholeiitic basalts. They are divided into four major types: aphyric basalts are the most abundant, followed by olivine-plagioclase-clinopyroxene phyric basalts, olivine-plagioclase phyric rocks, and olivine-plagioclase-clinopyroxene-spinel-bearing basalts. Olivine-plagioclase and plagioclase-

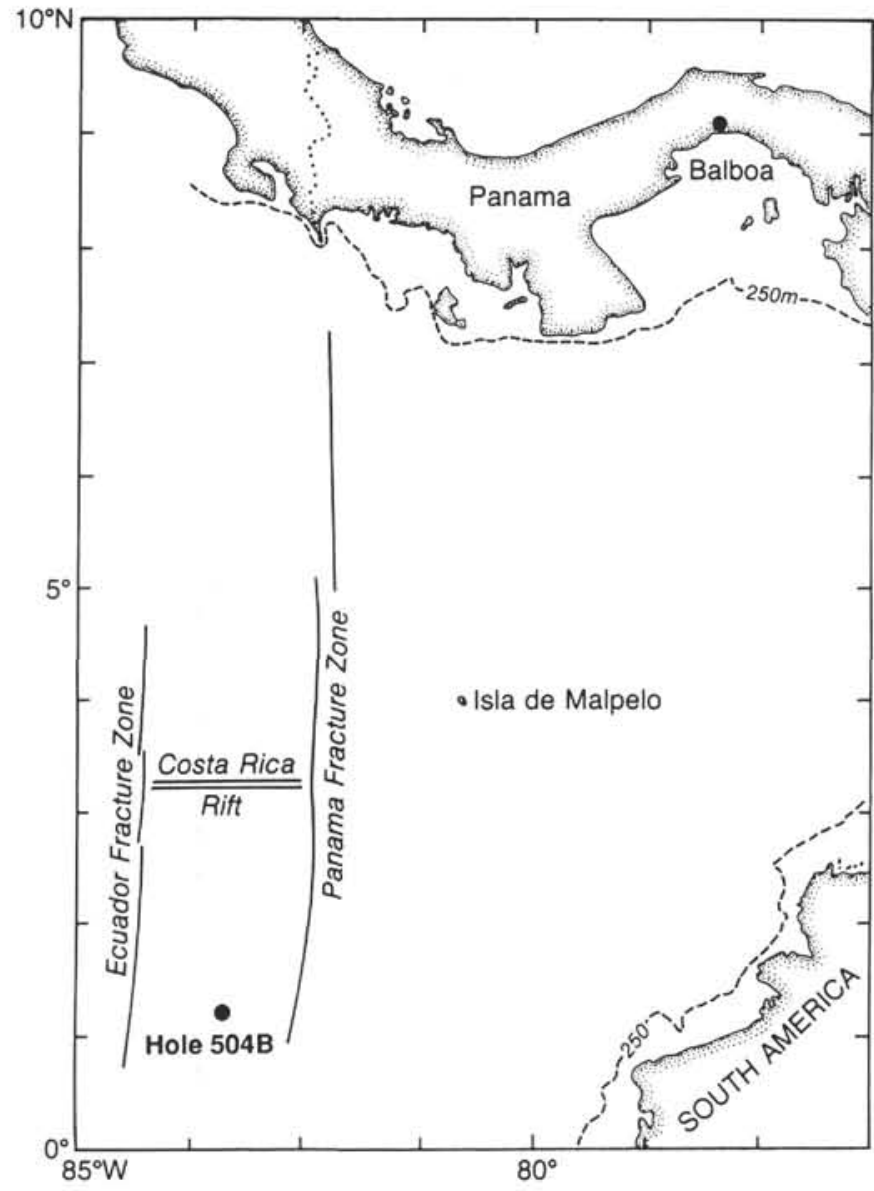

Figure 1. Location of DSDP/ODP Hole 504B in the eastern equatorial Pacific.

clinopyroxene basalts occur deeper in the hole, and aphyric rocks become more abundant with depth in the dike section. A remarkable feature of the basalts is that there are generally only slight variations in their compositions throughout the entire volcanic and dike sections. Basalt compositions are similar to moderately evolved midocean ridge basalt (MORB), with $\mathrm{Mg}$ numbers mostly in the range 0.63-0.74 (Autio and Rhodes, 1983; Kempton et al., 1985; Autio et al., 1989; Kusakabe et al., 1989; Zuleger et al., 1995; Bach et al., this volume). The rocks are unusually depleted in incompatible elements $\left(\mathrm{TiO}_{2}=0.7 \%-1.2 \%, \mathrm{Nb}<0.3-1.3 \mathrm{ppm}, \mathrm{Zr}=35-60 \mathrm{ppm}\right)$, but have incompatible element ratios comparable to normal I-type MORB as defined by Bryan et al. (1976). The refractory nature of the basalts is also illustrated by their high $\mathrm{CaO} / \mathrm{Na}_{2} \mathrm{O}$ ratios (5-8), which are in equilibrium with exceptionally calcic plagioclase at liquidus temperatures. The basalts have been interpreted as being very primitive (Natland et al., 1983; Emmermann, 1985), or the result of multistage melting of a normal MORB mantle source followed by moderate extents of crystal fractionation (Autio and Rhodes, 1983; Kempton et al., 1985; Autio et al., 1989). The exceptional overall uniformity in composition of the basalts has been interpreted to indicate the presence of a steady-state magma chamber beneath the rift axis (Natland et al., 1983). Three units (two volcanic and one dike) are enriched- or transitional-type MORB, and comprise $\sim 1 \%$ of the core (Autio and Rhodes, 1983; Emmermann, 1985). A separate mantle source has been suggested for these rocks (Emmermann, 1985), but their origin remains problematic. It is possible that these units could be late, off- 


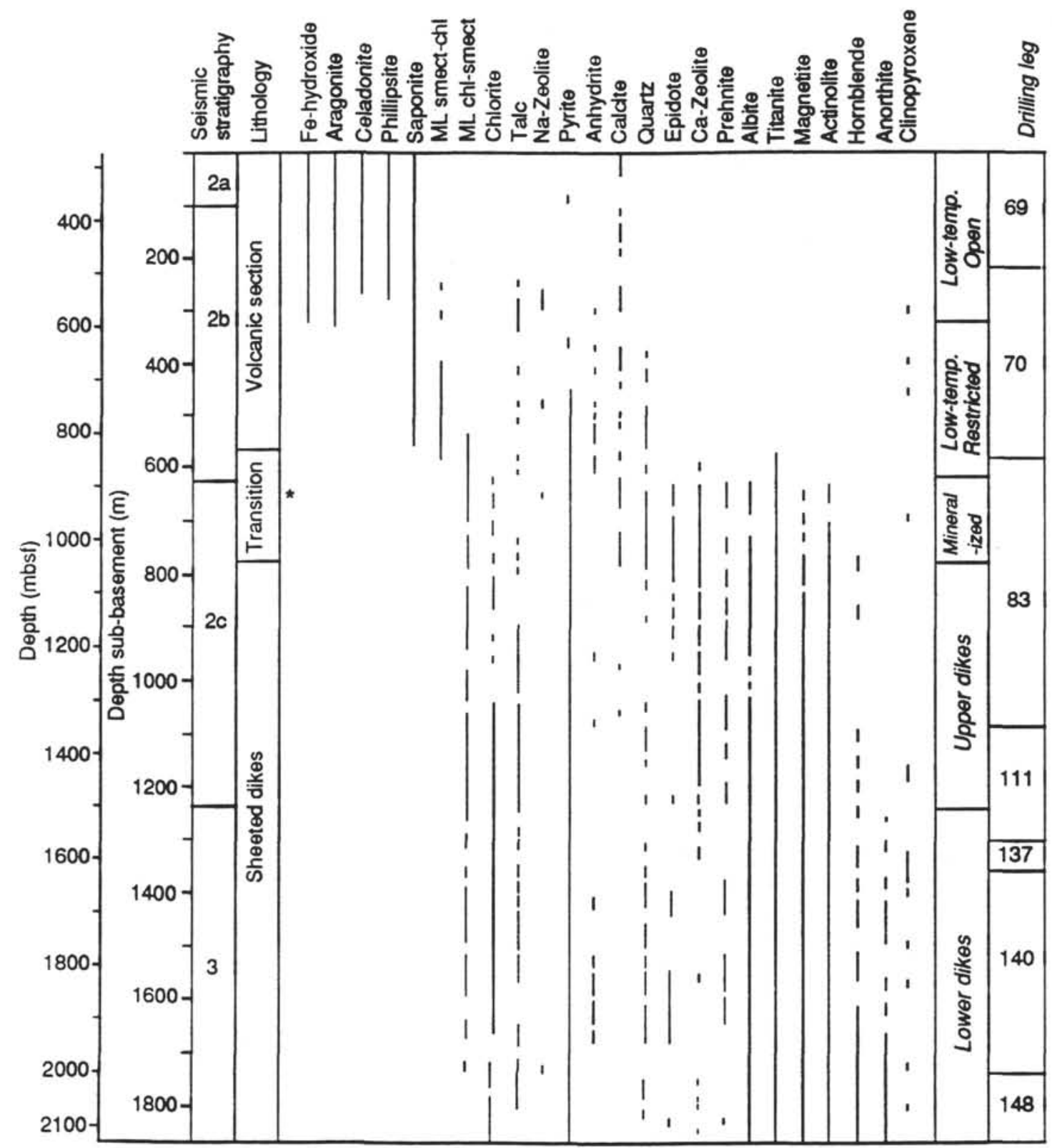

Figure 2. Lithostratigraphy and distribution of secondary minerals in Hole 504B (after Alt et al., 1986a: Laverne et al., 1995; Vanko et al., this volume). Also shown at right are the penetration depths for the various drilling legs. Asterisk indicates location of stockwork-like sulfide mineralization in the transition zone. $\mathrm{ML}=$ mixed-layer, $\mathrm{chl}=$ chlorite, and smect $=$ smectite.

axis enriched rocks like those found near the East Pacific Rise at $9^{\circ} \mathrm{N}$ (Perfit et al., 1994).

The petrography of the dikes is similar throughout the dike section, and is described in detail elsewhere (Kempton et al., 1985; Kusakabe et al., 1989; Dick, Erzinger, Stokking, et al., 1992; Alt, Kinoshita, Stokking, et al., 1993; Laverne et al., 1995; Vanko et al., this volume). The rocks are fine- to medium-grained diabase dikes, comprising olivine, clinopyroxene, plagioclase, and accessory titanomagnetite, trace sulfides, and minor spinel. Variable amounts $(1 \%-8 \%)$ of plagioclase phenocrysts, glomerocrysts, and megacrysts are present. The phenocrysts are mainly bytownite $\left(\mathrm{An}_{70}-\mathrm{An}_{80}\right)$ in composition, but the cores of plagioclase megacrysts range up to $\mathrm{An}_{90}$. Plagioclase phenocrysts and megacrysts commonly exhibit magmatic zonations, with the calcic cores having a sharp break in composition to a variably zoned mantle, about $0.1 \mathrm{~mm}$ wide, which is in turn rimmed by more sodic plagioclase similar to groundmass plagioclase
$\left(\mathrm{An}_{47-75} ;\right.$ Kempton et al., 1985; Kusakabe et al., 1989; Dick, Erzinger, Stokking, et al., 1992; Alt, Kinoshita, Stokking, et al., 1993; Laverne et al., 1995; Vanko et al., this volume). Olivine phenocrysts $\left(\mathrm{Fo}_{85-87}\right)$ generally make up $1 \%-2 \%$ of the rocks, and augitic clinopyroxene phenocrysts are present in amounts less than $2 \%$. Clinopyroxene phenocrysts are commonly zoned, from endiopsidic cores to more $\mathrm{Fe}$ rich rims (Kempton et al., 1985; Kusakabe et al., 1989). Increases in $\mathrm{Al}$ and then $\mathrm{Ti}$ contents also occur progressively outward from clinopyroxene phenocryst cores to rims (Kempton et al., 1985; Kusakabe et al., 1989).

\section{VOLCANIC SECTION (274.5-846 mbsf)}

On the basis of the recovered core, the volcanic section consists mainly of pillow basalts $(57 \%)$, with common massive units (22\%), 


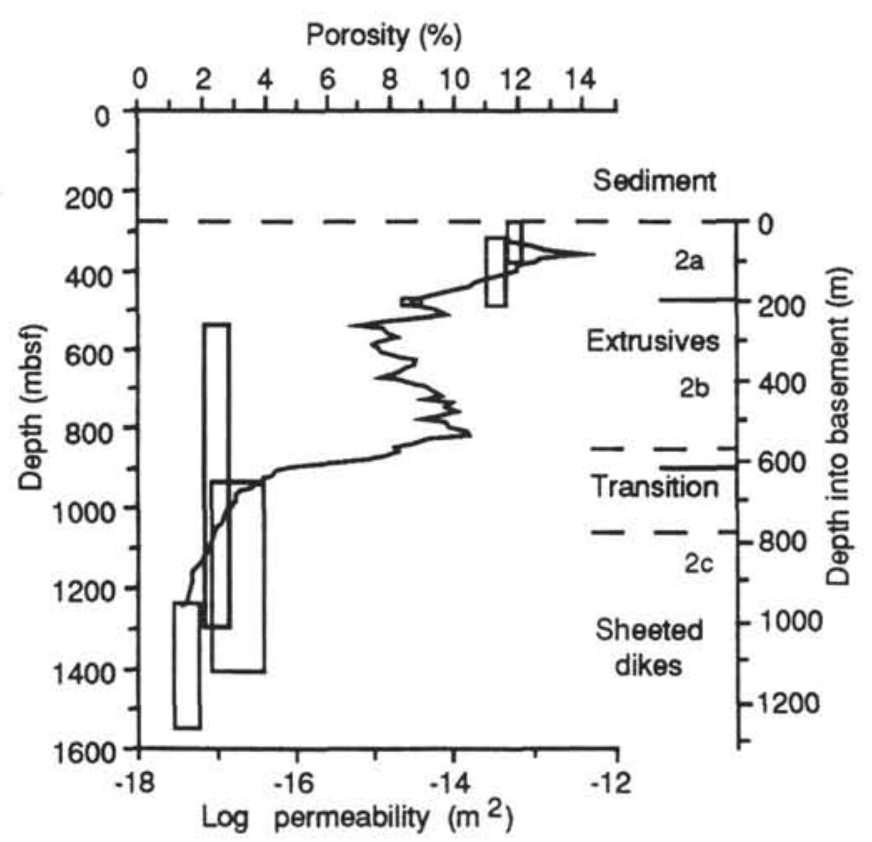

Figure 3. Variation of apparent bulk porosity of basement with depth in Hole 504B determined by applying Archie's Law to large-scale electrical resistivity logs, and bulk permeabilities measured over the intervals spanned by the vertical bars. Approximate boundaries of seismic layers are shown at right (from Becker, Sakai, et al., 1988).

thin flows (17.5\%), and minor dikes (3\%; Adamson, 1985). Detailed measurements of core indicate that the $57 \%$ pillow basalts include $9 \%$ breccia material (Alt et al., this volume). Although there is no good correlation of recovery with rock type in recovered core (Alt et al., this volume), electrical resistivity logs suggest that core recovery is biased toward the massive units, and that pillow basalts (plus breccias) actually comprise about $70 \%$ of the section, with massive units and thin flows making up about $13 \%$ each and dikes about $4 \%$ (Pezard, 1990). If breccias are preferentially lost during coring, then breccias could comprise a maximum of about $17 \%$ of the section (i.e., the difference between recovered pillow basalts and the proportion indicated by the resistivity $\log$ ).

Low sonic velocities in the upper $100-200 \mathrm{~m}$ indicate the presence of highly porous and permeable volcanic rocks of seismic Layer 2A (Fig. 3; Newmark et al., 1985). Layer 2B comprises the lower 500 $\mathrm{m}$ of volcanic rocks, in which the original porosity has been mostly sealed by secondary minerals (Becker, 1985; Pezard, 1990). Temperature measurements in the borehole before drilling were made on several legs, indicating variable rates of flow of bottom seawater down the hole and out into an aquifer within Layer $2 \mathrm{~A}$ in the upper $100 \mathrm{~m}$ of basement (Pezard et al., 1992; Becker, Foss, et al., 1992).

The volcanic section can be divided into upper and lower alteration zones (274.5-594 and 594-846 mbsf; Fig. 2; Honnorez et al., 1983; Alt et al., 1986a). All of the basalts from throughout the volcanic section are slightly altered $(5 \%-15 \%)$, and three basic alteration types can be distinguished: dark-gray rocks occur throughout the volcanic section, whereas red and black alteration halos occur in the upper alteration zone. The dark-gray rocks are characterized by the presence of saponite, which partly to totally replaces olivine, fills pores and fractures, cements breccias, and partly replaces plagioclase and glassy pillow rims. Small amounts of talc are also present. Carbonates and minor pyrite are typical accessory minerals, and rare Kfeldspar and albite occur in a few samples. Red alteration halos, $0.5-$ $2 \mathrm{~cm}$ wide, occur along fractures in the upper alteration zone (Fig. 4). The alteration and secondary mineralogy of these zones are similar to

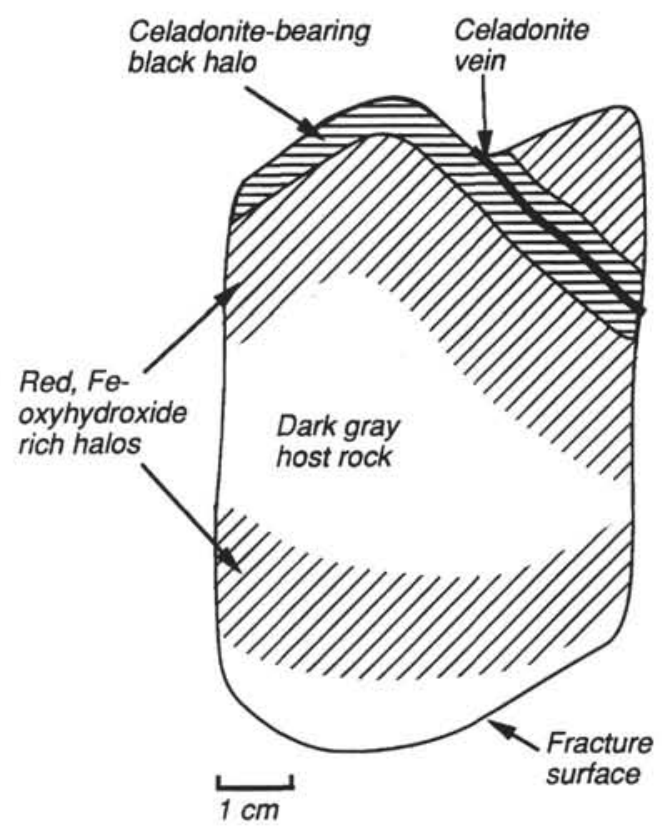

Figure 4. Sketch of a sample from the upper volcanic section, showing typical geometries of red and black alteration halos (after Honnorez et al., 1983; Alt et al., 1986a).

the dark-gray rocks, but abundant Fe-oxyhydroxides replacing olivine, disseminated in the groundmass, and staining saponite impart a reddish color to the rocks. Recent logging of the Hole 504B drill core reveals that red halos comprise $27 \%$ of the upper volcanic section (Alt, 1995). Narrow black alteration halos, up to $0.5 \mathrm{~cm}$ wide, occur along one side of or within the red halos (Fig. 4); they are characterized by the presence of celadonite, in addition to saponite and $\mathrm{Fe}$ oxyhydroxides, which is replacing olivine and filling pores. Fractures throughout the volcanic section are filled mainly with saponite, but carbonates (aragonite and calcite) and phillipsite are common in small amounts. Celadonite also occurs in some fine veins in the upper volcanic section, and small amounts of quartz and anhydrite occur in veins and breccias of the lower volcanic section.

Bulk rocks from the upper volcanic section exhibit increased $\mathrm{K}$, $\mathrm{Rb}, \mathrm{B}, \mathrm{CO}_{2}$, and $\mathrm{H}_{2} \mathrm{O}$ contents, elevated $\delta^{18} \mathrm{O}, \delta \mathrm{D}, \delta^{11} \mathrm{~B}$, and ${ }^{87} \mathrm{Sr} /{ }^{86} \mathrm{Sr}$, and lower $\mathrm{S}$ contents and $\delta^{34} \mathrm{~S}$ relative to least-altered rocks and fresh glass compositions (Figs. 5, 6; Barrett, 1983; Barrett and Friedrichsen, 1982; Honnorez et al., 1983; Hubberten, 1983; Noack et al., 1983; Alt et al., 1986a, 1986b, 1989a; Ishikawa and Nakamura, 1992). The red and black halos generally exhibit the greatest chemi$\mathrm{cal}$ and isotopic changes. The lower volcanic section exhibits chemical changes similar in direction to those of the upper volcanic section, but generally of smaller magnitude. The mineralogical and chemical changes reflect low-temperature alteration by seawater, with generally decreasing seawater influence downward. The upper section was altered by larger volumes of seawater, freely circulating through the uppermost volcanic pile, causing the greater oxidation and alkali-enrichment of those rocks (Fig. 7). Estimates of integrated seawater/ rock mass ratios of seawater required to produce the chemical changes observed in the volcanic section range from 2 to 900 , but the most reasonable values are probably about 10-100, with the higher ratios in the upper volcanic section (Alt et al., 1986b). Smectites (saponite) from the volcanic section exhibit varying $\mathrm{FeO} / \mathrm{FeO}+\mathrm{MgO}$ ratios with depth (Fig. 8). Saponites in the upper volcanic section have generally lower ratios, reflecting the more oxidizing conditions and partitioning of ferric iron into Fe-oxyhydroxides (Alt et al., 1986a). Higher ratios in the lower volcanic section are consistent with more 
reducing conditions there and incorporation of greater amounts of ferrous iron into smectite. Conditions throughout the volcanic section are interpreted to have evolved from more open and oxidizing to more restricted circulation of seawater and evolved fluid compositions (e.g., lower $\mathrm{Mg} / \mathrm{Ca}$ ratio; Alt et al., 1986a). Estimates of alteration temperatures from oxygen isotope ratios for the lower volcanic section range from $0^{\circ}$ to $40^{\circ} \mathrm{C}$ for vein carbonates, and up to $70^{\circ}-$ $140^{\circ} \mathrm{C}$ for vein smectites (Honnorez et al., 1983; Alt et al., 1986b; J.C. Alt, unpubl. data). Present temperatures in the volcanic section range from $60^{\circ} \mathrm{C}$ at the basement-sediment interface to about $110^{\circ} \mathrm{C}$ at the base of the lava pile (Becker, Foss, et al., 1992), indicating that the section has been conductively reheated since formation of the vein carbonates. Alteration of the volcanic section probably began at the axis, but could have continued for several million years. Hydrothermal circulation continues in the uppermost few hundred meters of basement today, and cementation and alteration of this portion of the crust may be currently taking place. No significant differences between alteration of rocks from this interval and from the immediately underlying rocks have been observed, however.

Water within the borehole was sampled before drilling on Legs $70,83,92,111,137$, and 148 in attempts to sample basement formation waters. These efforts met with variable success, partly because of sampling problems. The borehole waters exhibit significant differences in composition from seawater, which are attributed to reaction with basaltic basement (Hart and Mottl, 1983; Mottl and Gieskes, 1990; Magenheim et al., 1995). Guerin et al. (this volume) suggest that slight perturbations of the temperature profile in the borehole measured after drilling could be the result of drill water from the preceding drilling operations entering the borehole. This might imply that there could be zones where basement formation fluids enter the borehole as well, but these zones are more likely areas of drillinginduced fracturing (Pezard et al., this volume; Ayadi et al., this volume). Magenheim and Gieskes (this volume) and Magenheim et al. (1995) conclude that gradients in borehole water chemistry are the result of reaction of surface seawater that was pumped into the hole with basaltic rubble at the bottom of the hole.

In addition to the general alteration described above, a zeolite-rich interval occurs from 528.5 to $563 \mathrm{mbsf}$. This zone is characterized by abundant, thick (up to $2 \mathrm{~cm}$ ) veins of zeolites, zeolite-cemented breccias, and $1 \mathrm{~cm}$ wide, zeolite-rich alteration halos in the host basalts. Minerals in these veins and rocks include saponite, celadonite, Feoxyhydroxides, natrolite, mesolite, thompsonite, analcite, apophyllite, gyrolite, aragonite, and calcite. These effects are superimposed upon the typical upper alteration zone red halos and dark-gray host rocks, and represent some kind of late, focused fluid flow (Honnorez et al., 1983; Alt et al., 1986a).

A change in magnetic inclination at about $800 \mathrm{mbsf}$ in the lower volcanic section suggests that a fault may be present, causing slight tilting of the volcanic section (Kinoshita et al., 1989). Clay-cemented breccias are common from the lower volcanic section (Cann et al., 1983; Alt et al., this volume), and the resistivity log shows a minimum at about 800 mbsf indicating increased fracturing at this depth (Fig. 9; Pezard et al., this volume). Evidence for small-scale offsets implying the presence of a fault has also been documented from detailed study of slightly deeper rocks (840-958 mbsf; Agar, 1991).

\section{TRANSITION ZONE AND UPPER DIKE SECTION (846-1500 mbsf)}

\section{Alteration Mineralogy}

The lithologic transition zone (846-1055 mbsf) is by definition gradational. The upper boundary in Hole 504B is defined by the occurrence of 4 dikes within $60 \mathrm{~m}$, and the lower boundary is marked by the last identifiable pillow basalt (Adamson, 1985). The physical properties of the crust measured in situ change significantly across the transition zone: sonic velocities increase sharply whereas bulk permeability and porosity drop by orders of magnitude (Fig. 3;
Anderson et al., 1982). The sonic data are generally consistent with a sharp boundary between Layers $2 \mathrm{~B}$ and $2 \mathrm{C}$ that coincides with the top of the sheeted dikes (Salisbury et al., 1985), whereas the petrological boundary is transitional.

The rocks of the transition zone are mainly highly fractured, hydrothermally altered and brecciated pillows and dikes (Alt et al., $1985 \mathrm{a}, 1986 \mathrm{a}, 1989 \mathrm{~b})$. In the upper $\sim 50 \mathrm{~m}$ of this zone (846-898 mbsf), the alteration is generally similar to that in the overlying lower volcanic section, with the exception of the presence of sphene, mixed-layer smectite-chlorite, minor laumontite, and more abundant anhydrite in the transition zone rocks (Fig. 2). Then, at $898 \mathrm{mbsf}$, hydrothermally altered rocks appear abruptly. These range from darkgray, slightly recrystallized $(20 \%-30 \%)$.rocks to light greenish and gray, intensively recrystallized rocks (mostly $50 \%-75 \%$ but up to $100 \%$ recrystallized). Plagioclase is partly to totally replaced by albite-oligoclase, and minor laumontite, heulandite, and chlorite. Generally it is only the calcic cores of phenocrysts that are replaced, whereas the sodic rims and groundmass plagioclase remain intact. Olivine is replaced by chlorite + quartz, or mixed-layer smectitechlorite; pyroxene is rimmed and partly replaced by actinolite plus micrometer-sized magnetite blebs; and titanomagnetite is extensively replaced by titanite. Glass at pillow rims is replaced by chlorite. Pyrite is commonly disseminated in the rocks and replaces silicates. Abundant veins are filled and breccias cemented with chlorite \pm actinolite, quartz, epidote, laumontite, minor heulandite, albite, and calcite, trace analcite, and common pyrite. A mineralized stockworklike zone containing abundant veins of quartz and sulfide minerals occurs in a highly fractured and brecciated pillow unit at 910-928 mbsf within the transition zone (Fig. 2; Honnorez et al., 1985).

Rocks of the upper dike section (1055-1500 mbsf) are light to dark gray and are variably recrystallized $(10 \%-100 \%)$, with lightgray, more intensively altered halos around chlorite \pm actinolite veins (Fig. 10). The secondary mineralogy of the upper dikes is generally similar to that of the transition zone, but calcite is absent, heulandite is less common, scolecite and prehnite become more abundant in veins and replacing plagioclase, and talc + magnetite replace olivine locally in the upper dikes (Fig. 2). Titanomagnetites are partly to totally altered to titanite, but ilmenite exsolution lamellae resulting from high-temperature oxidation become more abundant with depth (Pariso and Johnson, 1991). Veins are less abundant in the dikes than in the transition zone, and appear to generally decrease with depth in the upper dikes. Also present in coarser grained upper dike rocks are 1 to $7 \mathrm{~cm}$ sized, irregularly shaped light-gray alteration patches, where the rock is more intensively recrystallized than the host rock $(\sim 30 \%-100 \%$ vs. $\sim 10 \%-20 \%$; Fig. 10). Many of these patches contain 0.3 - to 1 -mm zoned amygdules filled with chlorite \pm actinolite \pm laumontite or scolecite. This indicates that these were zones of enhanced primary pore space and permeability in the rocks, allowing greater access of fluids and extent of reaction, similar to the alteration halos around veins. Approximately $17 \%$ of the upper dikes core consists of light-gray, intensively altered halos and patches (Alt, 1995).

Veins exhibit a consistent sequence of mineral precipitation in the upper dikes and transition zone. Chlorite \pm actinolite \pm titanite veins formed first, in some cases with narrow (hundreds of micrometer) silicified or chloritized wall-rock selvages. These are crosscut by quartz \pm epidote \pm sulfide veins, which are in turn cut or reopened by zeolite (laumontite and scolecite) and prehnite veins, and by calcite veins in the stockwork-like zone. Heulandite and prehnite partly replace quartz in veins. Anhydrite occurs in reopened chlorite \pm actinolite veins, and in one case is cut by a prehnite vein, but the relationship to quartz + epidote + sulfide veins is not directly observed.

The intensities of hydrothermal alteration and recrystallization of the upper dikes are highly variable, and are functions of fracturing and permeability of the rocks. From 1189 to 1336 mbsf and at $1350-$ $1480 \mathrm{mbsf}$, there are intervals of generally slightly altered, dark-gray rocks (Alt et al., 1985a, 1989a). Olivine is replaced by mixed-layer chlorite-smectite and talc + magnetite, but otherwise the rocks are lit- 

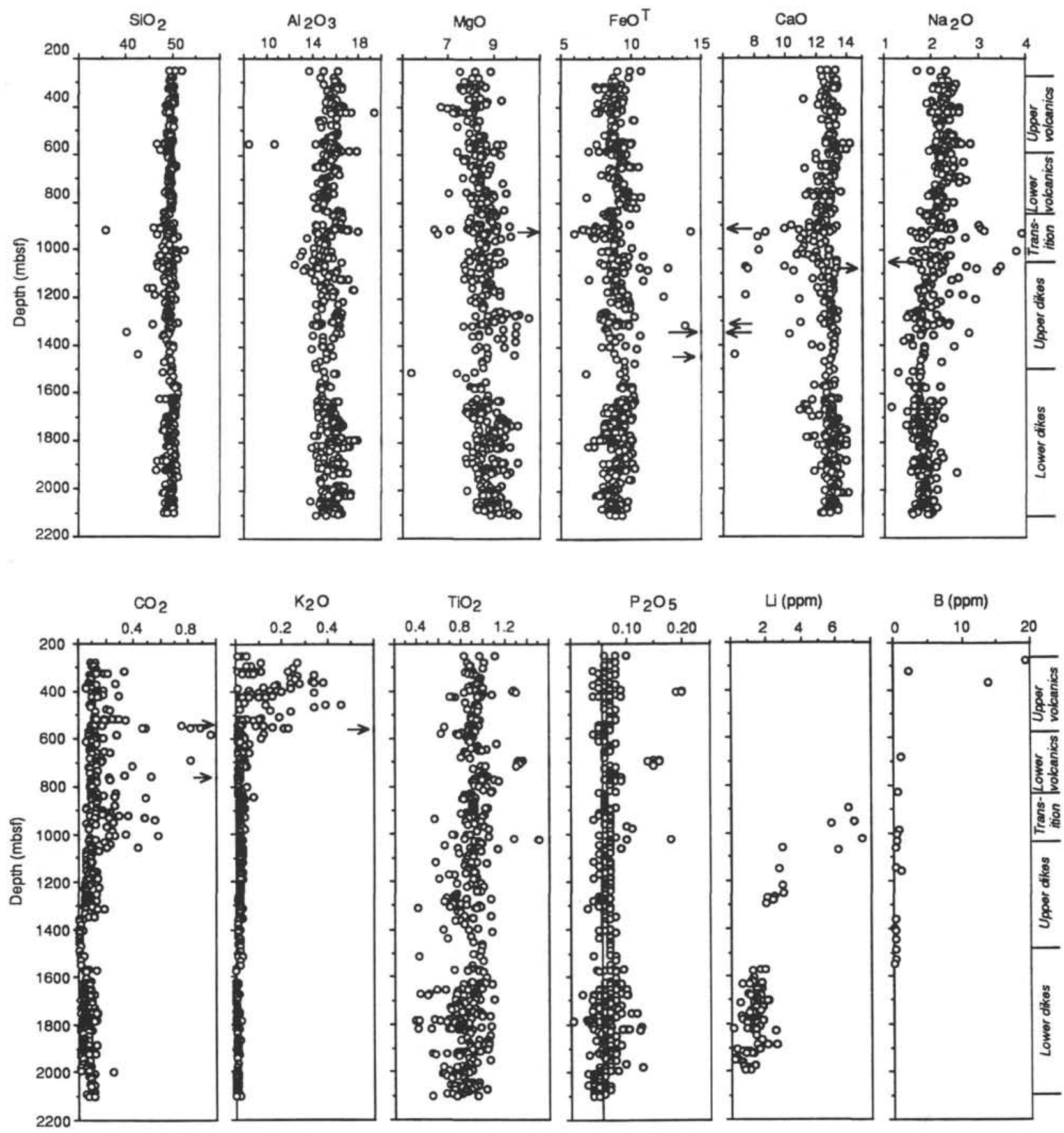

Figure 5. Whole-rock chemical compositions of rocks from Hole 504B (in wt\%; ppm where indicated). Data from Alt et al. (1986a, 1989a), Mengel and Hoefs (1990), Ishikawa and Nakamura (1992), Zuleger et al. (1995), and Bach et al. (this volume).

tle altered, and very few veins or fractures are present in the rocks. The borehole televiewer log indicates fewer and smaller fractures at 1189-1336 mbsf (Anderson, Honnorez et al., 1982), and the porosity determined from the resistivity log is generally low over both intervals (1189-1336 and 1350-1480 mbsf; Fig. 9; Pezard et al., this volume). In contrast, rocks from 1336 mbsf to 1350 mbsf and at 1437 mbsf are highly recrystallized and contain abundant veins (Alt et al., $1985 \mathrm{a}, 1989 \mathrm{a})$. The porosity determined from the resistivity log exhibits spikes to high values at $1336-1350 \mathrm{mbsf}$ and has a strong peak at 1437 mbsf, consistent with abundant clay-filled fractures (e.g., Fig. 9; Pezard et al., this volume). These observations were interpreted as evidence for permeability control of hydrothermal alteration, with zones of restricted fracturing and fluid flow exhibiting only slight recrystallization and limited chemical change (Alt et al., 1985a, 1986a, 1989a). The observed hydration of olivine to talc requires only addition of water to the rocks, whereas replacement of olivine by chlorite in more highly altered rocks requires further reaction and breakdown of plagioclase to provide a source of alumina to form chlorite (Alt et al., 1985a, 1986a). Thus, where decreased fracturing limited permeability and fluid access, alteration of the rocks was kinetically inhibited.

There is an increase in the extent of pyroxene alteration and abundance of actinolite, and a decrease in the intensity of plagioclase alteration downward from 1350 to $1550 \mathrm{mbsf}$ in the upper dikes. These 


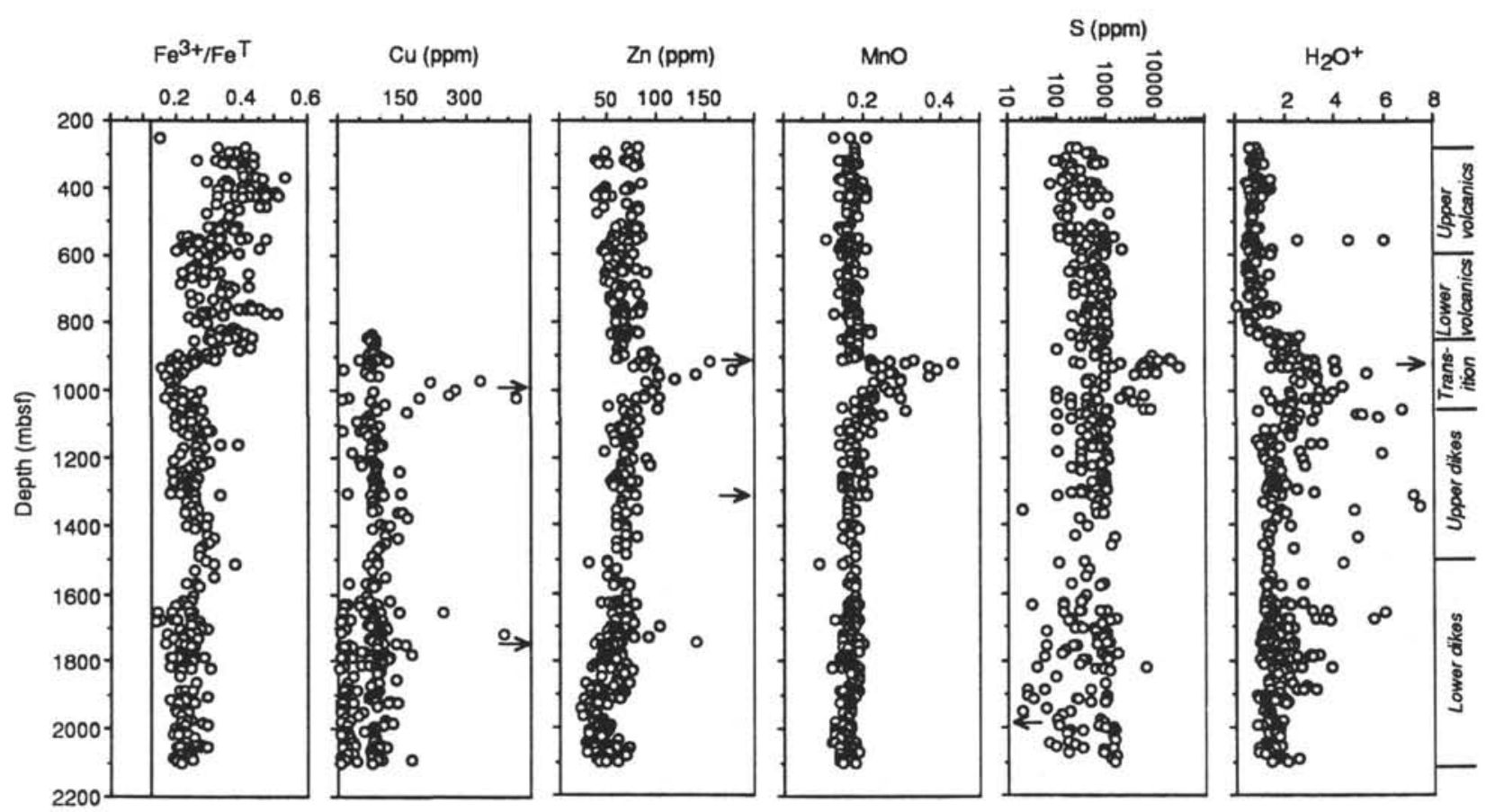

Figure 5 (continued).

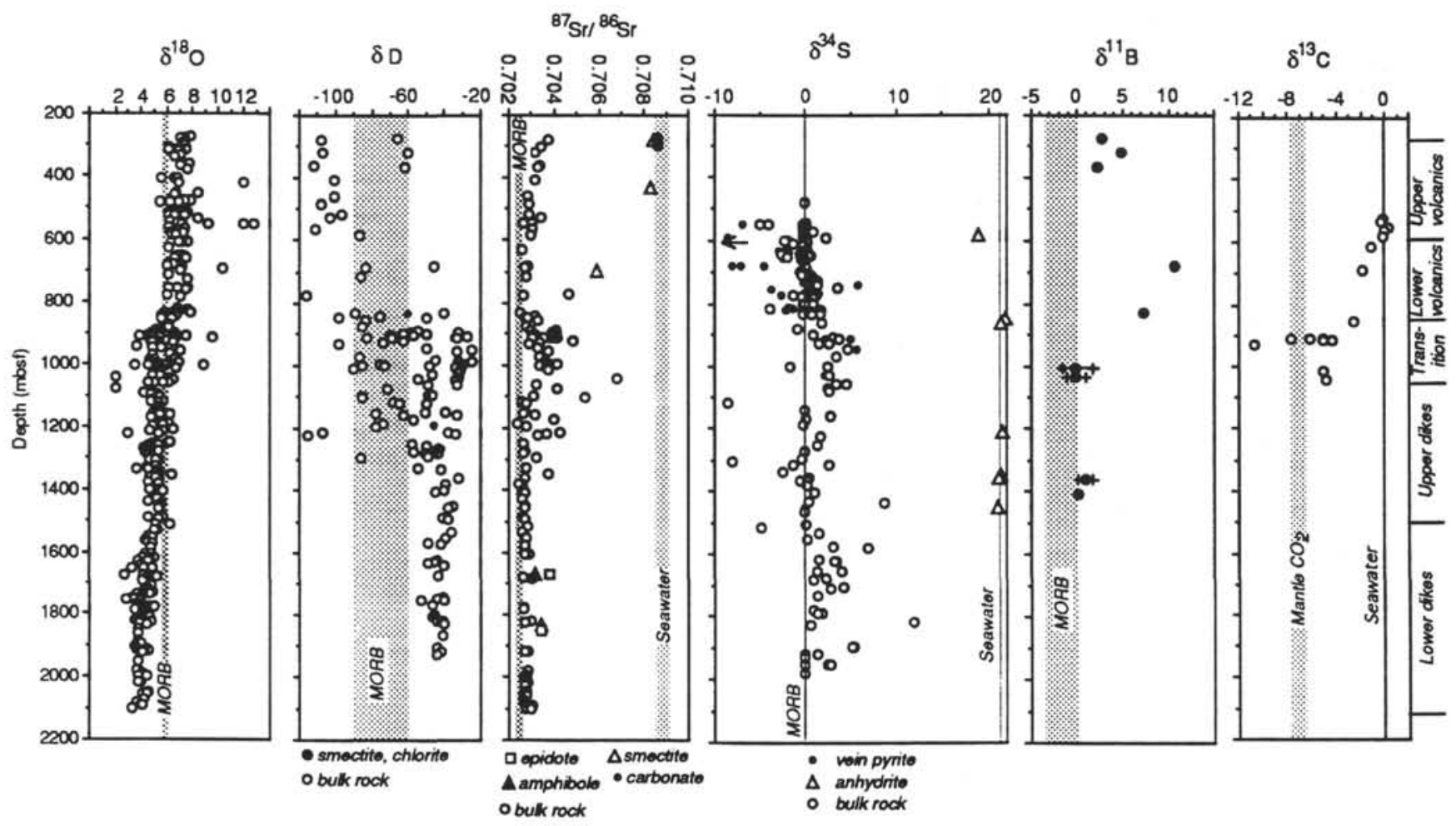

Figure 6. Isotopic data for rocks from Hole 504B ( $\delta$ values in per mil). Data is for whole rocks, except for $\delta^{13} \mathrm{C}$, which is for vein carbonates, and others as indicated. Errors are smaller than plotted points, except for $\delta$ "'B, where bars indicate where errors are larger. Data from Barrett (1983), Barrett and Friedrichsen (1983), Friedrichsen (1985), Alt et al. (1986b, 1989a, 1989b, 1995, this volume), Kawahata et al. (1987), Nesbitt et al. (1987), Shimizu et al. (1989), Mengel and Hoefs (1990), Ishikawa and Nakamura (1992), Hart et al. (1994), and Agrinier et al. (1995). Vertical lines and shaded bars indicate MORB and seawater compositions. 


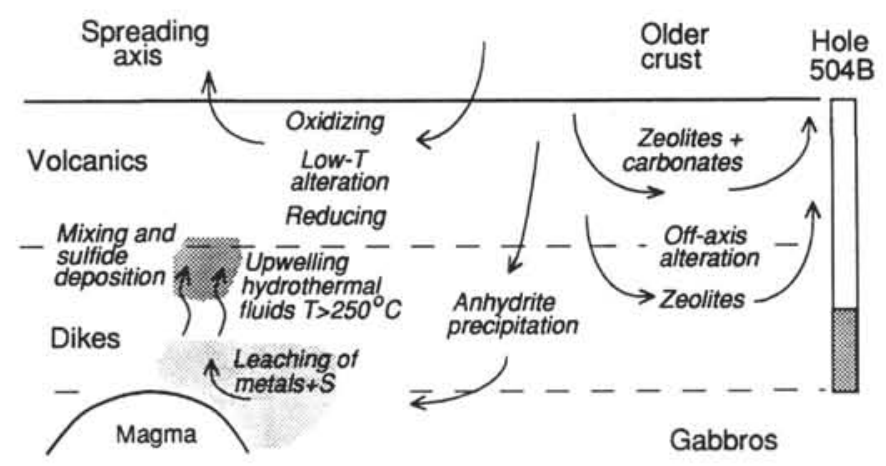

Figure 7. Schematic illustration of alteration stages undergone by the various parts of the crust as Site 504 moved away from the spreading axis by means of seafloor spreading (after Alt et al., 1986a, 1995, this volume). Hole 504B penetration shown at right.

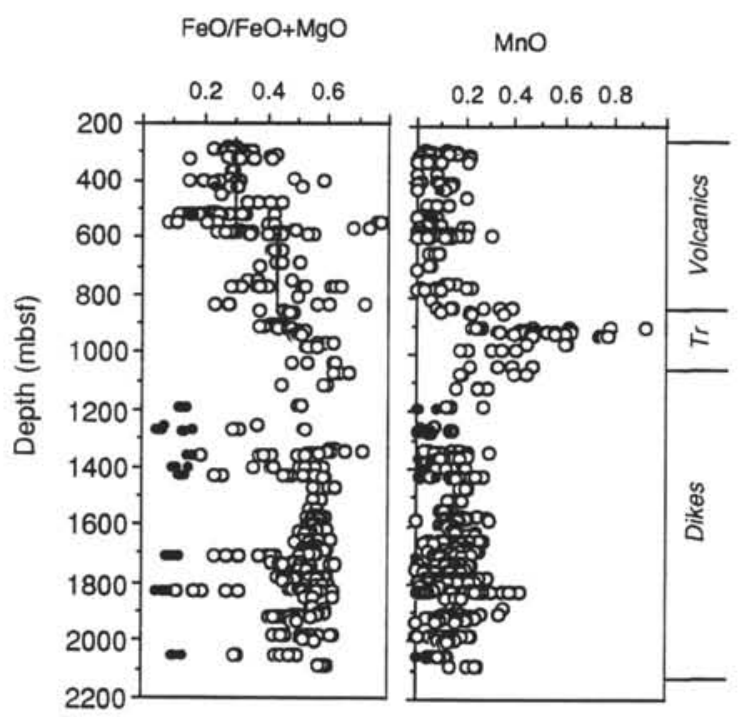

Figure 8. Compositions (wt\% oxides) of phyllosilicate minerals from Hole 504B. Open circles indicate smectite, chlorite, and mixed-layer phases, and solid circles indicate talc. Although the scatter is significant, the mean $\mathrm{FeO} /$ $\mathrm{FeO}+\mathrm{MgO}$ value for saponite from the upper volcanic section is lower than that from the lower volcanic section (vertical lines). The $\mathrm{FeO} / \mathrm{FeO}+\mathrm{MgO}$ of chlorites in the transition zone and dikes (below $900 \mathrm{mbsf}$ ) are relatively constant, but mixed-layer chlorite-smectites trend to lower ratios, toward talc. High $\mathrm{MnO}$ contents of chlorite in the transition zone lead to high bulk-rock MnO contents (see Fig. 5). Data from Honnorez et al. (1983), Alt et al. (1985a, 1986a, 1989a, 1995, this volume), Laverne et al. (1995), and Vanko et al. (this volume).

trends were interpreted to reflect increasing temperatures of alteration deeper in the dikes (Becker, Sakai, et al., 1988; Alt et al., 1989a), and were substantiated upon further drilling (Dick, Erzinger, Stokking, et al., 1992; Alt, Kinoshita, Stokking, et al., 1993). Similarly, the increasing abundance of ilmenite exsolution lamellae in igneous titanomagnetite with depth in the upper dikes was interpreted to reflect slower cooling and higher alteration temperatures downward in the dike complex (Pariso and Johnson, 1991).

Epidote from the transition zone and upper dikes has $\mathrm{Fe} / \mathrm{Fe}+\mathrm{Al}$ ratios of $0.16-0.28$, whereas prehnites exhibit a range of $0.01-0.20$ (Fig. 11). Ishizuka (1989) showed that prehnite and epidote coexisting with laumontite apparently have higher $\mathrm{Fe} / \mathrm{Fe}+\mathrm{Al}$ than prehnite and epidote associated with actinolite. The $\mathrm{Fe} / \mathrm{Fe}+\mathrm{Al}$ ratios of prehnite and epidote coexisting with laumontite are close to the predicted

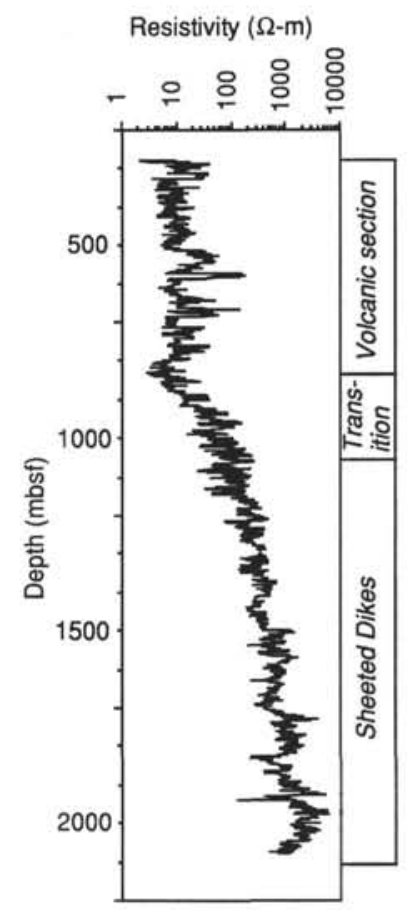

Figure 9. Resistivity log for Hole 504B (from Dick, Erzinger, Stokking, et al., 1992). Porosity is inversely related to resistivity, so high resistivity indicates low porosity (see Fig. 3 and Pezard et al., this volume).

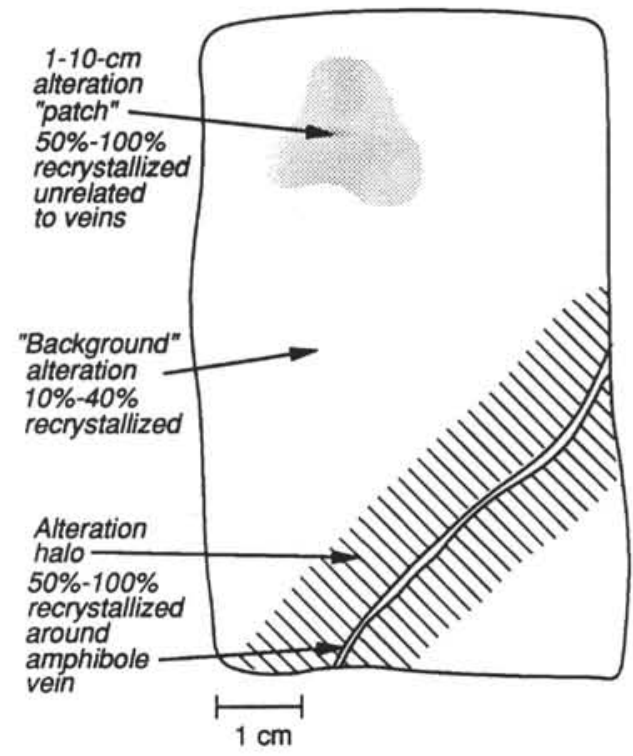

Figure 10. Sketch illustrating alteration features of a sample from the sheeted dike section (after Alt et al., 1995, this volume).

equilibrium exchange for these minerals (Bird et al., 1984), suggesting that these associations may represent equilibrium assemblages. The actinolite assemblage reflects higher temperatures, but the $\mathrm{Fe}$ contents of prehnite and epidote can also decrease as the oxygen fugacity decreases (Liou et al., 1983). Epidote occurrences and compositions also vary widely in Hole 504B. For example, epidote crystals commonly exhibit patchy zoning, with $\mathrm{Fe} / \mathrm{Fe}+\mathrm{Al}$ ratios varying by up to 0.09 within a single crystal. Moreover, X-ray diffraction reveals the presence of small amounts of clinozoisite, undetected by microprobe, in epidote separates (Alt et al., 1985a). Therefore, cau- 

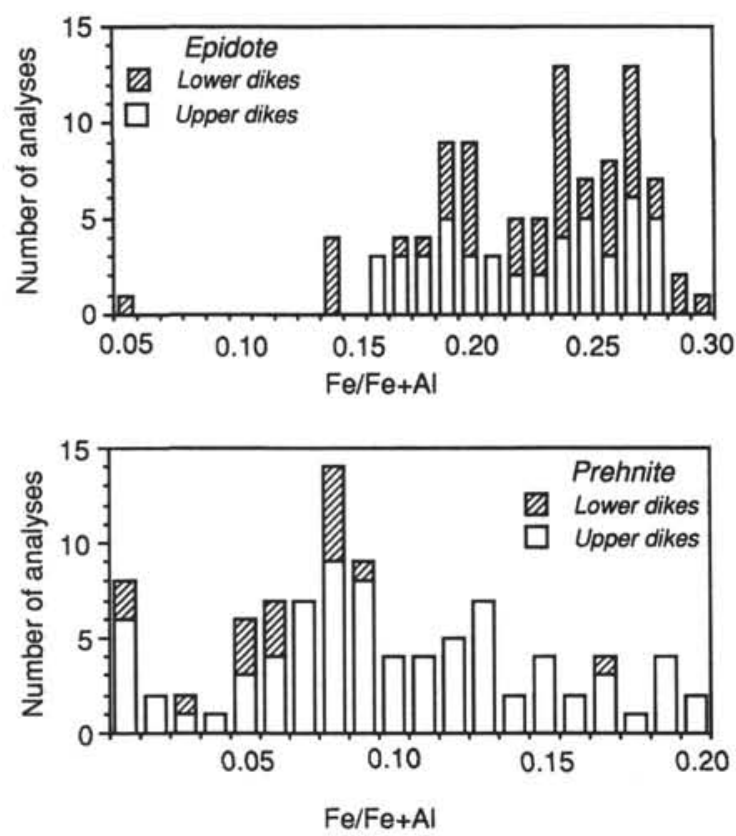

Figure 11. $\mathrm{Fe}^{3+} / \mathrm{Fe}^{3+}+\mathrm{Al}$ ratios for epidotes and prehnites from Hole 504B. Data from Alt et al. (1985a), Laverne (1987a), Ishizuka (1989), Laverne et al. (1995), and Vanko et al. (this volume).
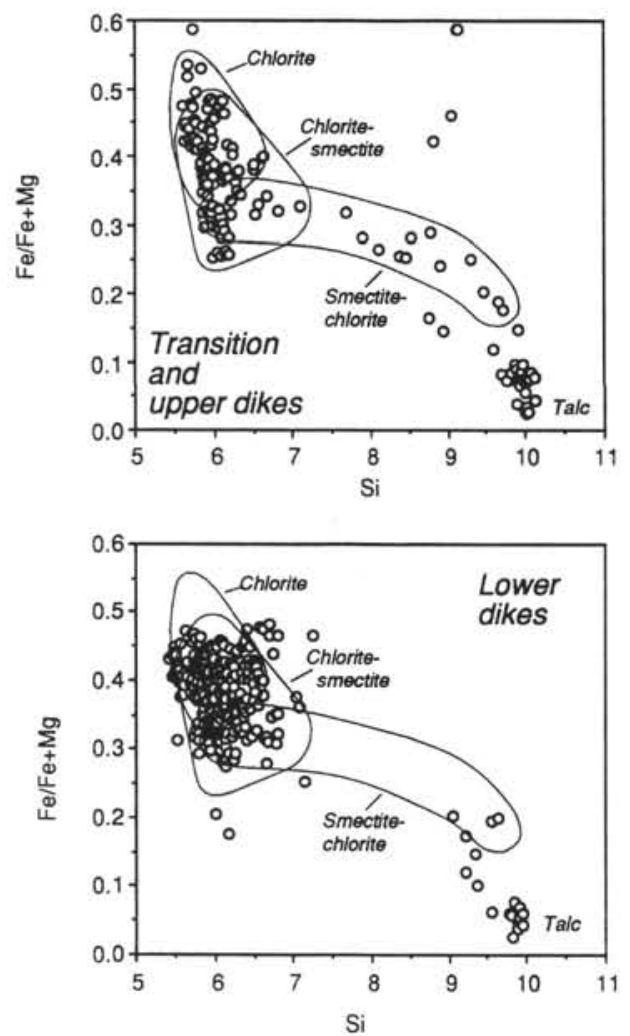

Figure 12. Compositions of phyllosilicates from the transition zone and sheeted dikes of Hole 504B. Formulas calculated on the basis of a layer charge of 56. Compositional fields of chlorite and mixed-layer phases identified by X-ray diffraction from Alt et al. (1985a). Data from Alt et al. (1985a, 1989a, 1995, this volume), and Vanko et al. (this volume).

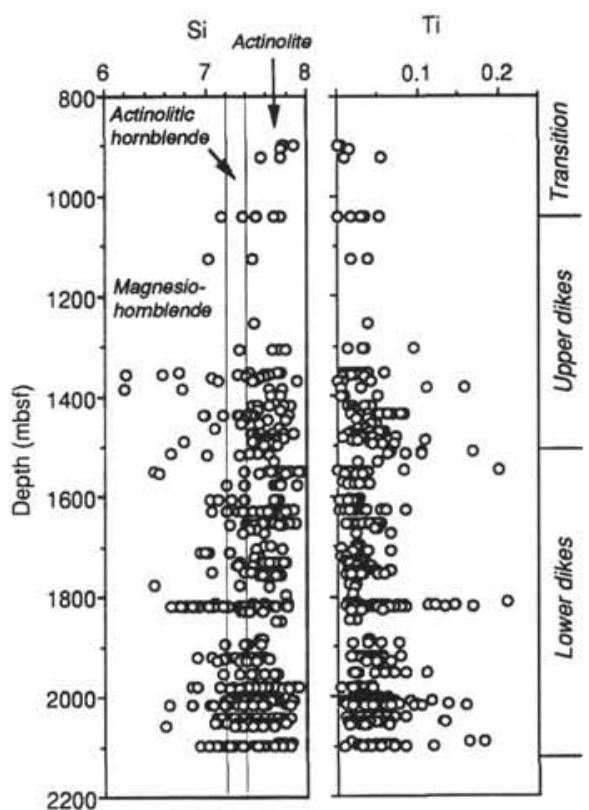

Figure 13. Compositions of amphiboles vs. depth in Hole 504B (atoms per 23 oxygens). Formulas calculated on the basis of 23 oxygens. Data from Alt et al. (1985a, 1989a, 1995, this volume), Ishizuka (1989), Laverne et al. (1995), and Vanko et al. (this volume).

tion must be used when applying mineral equilibria to secondary mineral assemblages in Hole 504B. The rocks generally reflect disequilibrium and reaction relationships between primary and secondary minerals and among various secondary minerals (Alt et al., 1985a).

A wide range of phyllosilicates is present in the transition zone and upper dikes. These range from true chlorite to random and regular interstratification of mixed-layer chlorite-smectites, to talc (Alt et al., 1985a, 1986a). The chlorites are ripidolites to pycnochlorites, and as the proportion of smectite layers increases the minerals exhibit trends to increasing $\mathrm{Si}$ and $\mathrm{Mg}$ and decreasing $\mathrm{Al}$ and $\mathrm{Fe}$ (Fig. 12; Alt et al., 1985a). This can also be seen in Figure 8, where the mixed-layer clays trend toward low $\mathrm{FeO} / \mathrm{FeO}+\mathrm{MgO}$ values and talc compositions. Talc contains minor smectite as indicated by the presence of small amounts of $\mathrm{Fe}$ and $\mathrm{Al}$ (Alt et al., 1985a). These observations have been confirmed by transmission electron microscope analyses (Shau and Peacor, 1992). Although there is a general trend from smectite in the volcanic section to chlorite in the transition zone and upper dikes, the mineralogy and distribution of phyllosilicates in these rocks are heterogeneous (Fig. 2). Thus, superimposed upon the general increase of temperature downward recorded by the transition from smectite to chlorite, are the effects of fracturing controlling access of fluids and causing kinetic effects on alteration of the rocks, as well as the multiple stages of alteration (see below).

Amphiboles in the transition zone are restricted to actinolite compositions. Amphiboles in the upper dikes are mainly calcic, but range to subcalcic compositions $(\mathrm{Ca}+\mathrm{Na}<1.34$ per 23 oxygens). Actinolite is the most common, but compositions can range to actinolitic hornblende or magnesiohornblende, even within a single thin section (Figs. 13, 14). Actinolites are locally Fe-rich (ferroactinolite). Small amounts of cummingtonite and anthophyllite were also identified locally replacing olivine (at $1360-1380$ and 1548 mbsf; Ishizuka, 1989).

\section{Alteration Processes}

The sequence of hydrothermal alteration in the transition zone and upper half of the dike section can be summarized in four stages, with 

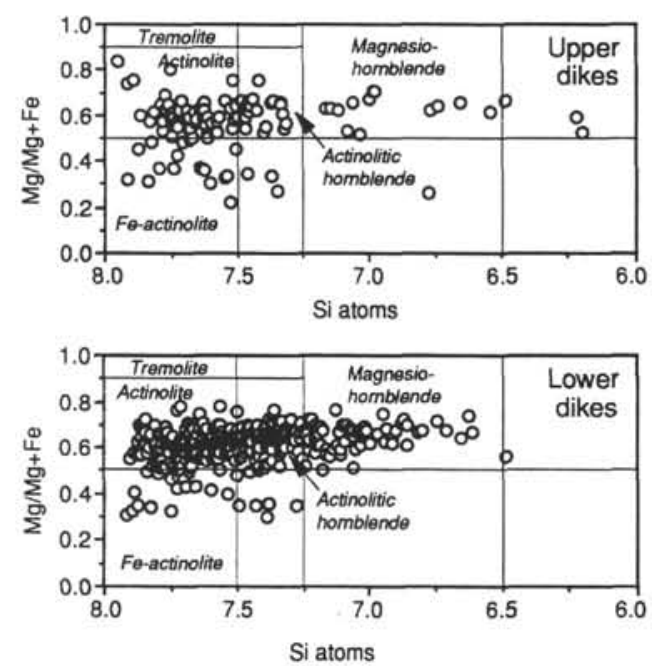

Figure 14. Compositions of amphiboles from Hole 504B plotted on classification diagram (from Leake, 1978). Data from Alt et al. (1985a, 1989a, 1995, this volume), Ishizuka (1989), Laverne et al. (1995), and Vanko et al. (this volume).

temperatures and fluid compositions constrained by secondary mineralogy, mineral chemistry and stable isotopic data (Fig. 7; Alt et al., 1985a, 1985b, 1986a, 1986b, 1989a, 1989b; Honnorez et al., 1985).

First, chlorite and actinolite formed in veins and greenschist minerals (chlorite, actinolite, albite-oligoclase, titanite, and local talc) formed in the host rocks during axial hydrothermal alteration by seawater hydrothermal fluids at temperatures of $\sim 200^{\circ} \mathrm{C}$ to $>300^{\circ} \mathrm{C}$.

Second, quartz, epidote and sulfides formed in veins at $250^{\circ}-$ $380^{\circ} \mathrm{C}$ from more highly reacted, evolved hydrothermal fluids that were depleted in $\mathrm{Mg}$ and enriched in $\mathrm{Ca}$, metals, and ${ }^{18} \mathrm{O}$. The stockwork-like sulfide mineralization formed in the transition zone, where hydrothermal fluids upwelling through the dikes mixed with cooler seawater solutions circulating in the overlying more permeable volcanic section. Carbonate mineral $\delta^{13} \mathrm{C}$ values exhibit a step-like decrease downward into the transition zone (Fig. 6), reflecting input of magmatic $\mathrm{CO}_{2}$ (about $-7 \%$ ) from below and mixing with seawater $\mathrm{CO}_{2}(0 \%$ ) from above (Alt et al., 1986b). Various evidence, such as secondary mineral precipitation and replacement sequences and compositional and isotopic zoning in sulfide crystals, document fluctuations in fluid chemistry and temperature as the result of fluid mixing in the transition zone during this stage (Alt et al., 1985a, 1986a, 1986b, 1989a, 1989b; Honnorez et al., 1985). A steep temperature gradient existed, with temperatures increasing from $\leq 100^{\circ}$ to $150^{\circ} \mathrm{C}$ in the lower lavas to up to $350^{\circ}-380^{\circ} \mathrm{C}$ in the transition zone over a vertical distance of about $70 \mathrm{~m}$. The appearance of titanite, mixedlayer chlorite-smectite, and the abundance of anhydrite at the top of the transition zone probably reflect this steep temperature gradient.

Later, as the crust moved off-axis into a recharge zone, fracturing and/or faulting allowed penetration of seawater into still-warm rocks, resulting in precipitation of anhydrite in cracks and local replacement of plagioclase by anhydrite. Anhydrites have $\delta^{34} \mathrm{~S}$ values identical to seawater sulfate, indicating little reaction or exchange of sulfur between rocks and recharge fluids (Alt et al., 1989a, 1989b).

Finally, zeolites, prehnite, and calcite formed in fractures and rocks during later off-axis alteration at lower temperatures $\left(<250^{\circ} \mathrm{C}\right)$, from more evolved hydrothermal fluids (increased $\mathrm{pH}$ and $\mathrm{Ca} / \mathrm{Mg}$ ). Vein calcites from the transition zone provide evidence for the lowest temperatures $\left(100^{\circ}-200^{\circ} \mathrm{C}\right)$ in this zone or the upper dikes (Alt et al., 1986b). In contrast to the reheating of the volcanic section, there is no evidence that the transition zone and upper dikes were ever cooled below their present temperatures, which range from $\sim 110^{\circ} \mathrm{C}$ at the top of the transition zone to $160^{\circ} \mathrm{C}$ at 1560 mbsf (Becker, Foss, et al., 1992).

\section{Bulk-Rock Chemical Changes}

The rocks of the upper dikes and particularly the transition zone exhibit striking chemical changes relative to the overlying lower volcanic section and compared to fresh rocks (Figs. 5, 6). These changes reflect elevated temperatures of alteration plus the effects of alteration in a subsurface mixing zone (Alt et al., 1985a, 1986a, 1986b, 1989a, 1989b; Alt and Emmermann, 1985; Emmermann, 1985; Friedrichsen, 1985). At about $910 \mathrm{mbsf} \mathrm{Cu}, \mathrm{Zn}, \mathrm{Mn}$, and $\mathrm{S}$ exhibit strong peaks that tail off downward as the result of formation of metal sulfide minerals and Mn-bearing chlorite in the mineralized rocks (Fig. 8; Alt et al., 1985a, 1986a, 1989b). Seawater sulfate was reduced through oxidation of ferrous iron in rocks and fluids in the mixing zone, resulting in elevated $\delta^{34} \mathrm{~S}$ values of the mineralized rocks, which decrease progressively downward (Alt et al., 1989a). $\mathrm{H}_{2} \mathrm{O}$ contents and ${ }^{87} \mathrm{Sr} /{ }^{86} \mathrm{Sr}$ ratios increase drastically as the extent of recrystallization of the rocks increases across the top of the transition zone. $\delta^{18} \mathrm{O}$ and $\delta \mathrm{D}$ exhibit stepwise decreases and increases, respectively, as the result of the much higher temperatures of alteration in the transition zone and dikes, and the consequent smaller mineral-water isotopic fractionations. Likewise, $\mathrm{K}_{2} \mathrm{O}$ and $\mathrm{Fe}^{3+} / \mathrm{Fe}^{\mathrm{T}}$ exhibit stepwise decreases downward, as $\mathrm{K}$ is leached from the rocks at higher temperatures. In contrast, $\mathrm{Li}$ is slightly enriched in the transition zone (Mengel and Hoefs, 1990). $\mathrm{CO}_{2}$ contents remain sporadically high in the transition zone, but decrease downward into the dikes, out of the mixing zone. $\mathrm{Al}_{2} \mathrm{O}_{3}$ and particularly $\mathrm{TiO}_{2}$ exhibit increased scatter to low values: $\mathrm{TiO}_{2}$ underwent limited mobilization and was lost from the rocks along fractures to form titanite in the veins. $\mathrm{SiO}_{2}$ exhibits a few low values, and $\mathrm{CaO}$ and $\mathrm{Na}_{2} \mathrm{O}$ may be depleted or enriched, respectively, as the result of albitization of calcic plagioclase. Slight primary negative Eu anomalies in the rocks disappear as the result of albitization, and $\mathrm{La} / \mathrm{Sm}$ ratios increase with alteration (Alt and Emmermann, 1985). Rare local $\mathrm{Ca}$ enrichments and $\mathrm{Na}$ depletions are the result of late zeolitization reactions. $\mathrm{FeO}^{\mathrm{T}}$ exhibits local enrichments that coincide with the occurrence of Fe-rich amphibole and chlorite, and which could conceivably be the result of reaction with Fe-enriched upwelling hydrothermal fluids (Alt et al., 1986a, 1989b).

Notably, the rocks do not exhibit increased $\mathrm{MgO}$ contents. One altered glassy pillow rim has high $\mathrm{MgO}$ and low $\mathrm{SiO}_{2}$ as the result of chloritization, similar to that described in dredged basalts (e.g., Humphris and Thompson, 1978), but other rocks do not show this Mg enrichment. Narrow, millimeter-sized chloritized zones along veins indicate locally intensive interaction with seawater requiring high integrated water/rock mass ratios of $\sim 65$ (assuming all $\mathrm{Mg}$ in seawater is taken up to form chlorite; Alt et al., 1986a, 1986b). In contrast, most of the rock interacted with small volumes of seawater (integrated water/rock mass ratios $\sim 1$ indicated by $\mathrm{Mg}$ uptake and calculated from oxygen isotope ratios; Alt et al., 1986a, 1986b) and reactions were probably kinetically limited. Despite the general lack of $\mathrm{Mg}$ increase in whole rocks, there still may be a net uptake of $\mathrm{Mg}$ by the upper dike section via chlorite filling fractures and cementing dike margin breccias (Alt et al., 1986a, this volume).

In general, alteration halos around veins and the centimeter-sized alteration patches exhibit the greatest chemical changes resulting from hydrothermal alteration. The host rocks have lower $\delta^{18} \mathrm{O}$ than the vein halos, however, making the host rock appear isotopically more "altered," whereas the halos are really the more intensively recrystallized rock. This is because of the presence of ${ }^{18} \mathrm{O}$-rich secondary albite in the halos and its absence in the host rocks (Alt et al., 1986b). The centimeter-sized alteration patches exhibit extreme chemical changes, but some of these may be primary features (e.g., low P and Ti contents; Zuleger et al., 1995; Bach et al., this volume). 


\section{LOWER DIKES (1500-2111 mbsf)}

\section{Alteration Mineralogy}

Macroscopic alteration of the lower sheeted dikes is generally similar to that of the upper dikes (Fig. 10), but significant changes in mineralogy and chemistry exist. These include the presence of secondary calcic plagioclase and clinopyroxene, increasing amphibole abundance, the common presence of magnesiohornblende, more common ilmenite exsolution in titanomagnetite, the presence of anhydrite locally within the rocks rather than in veins, generally increasing intensity of recrystallization, and losses of metals and sulfur from the lower dikes. The petrography of the lower dikes is described in detail elsewhere (Dick, Erzinger, Stokking, et al., 1992; Alt, Kinoshita, Stokking, et al., 1993; Alt et al., 1995, this volume; Laverne et al., 1995; Tartarotti et al., 1995; Vanko et al., this volume), and is briefly summarized here.

The lower sheeted dikes are fine- to medium-grained diabase dikes, with igneous petrography and primary compositions generally similar to the upper dikes. All samples exhibit at least some effects of hydrothermal alteration. The least altered rocks, which are dark gray in color, are affected by a pervasive "background" alteration and are $10 \%-40 \%$ recrystallized to secondary minerals. Olivine is generally totally replaced by chlorite, mixed-layer chlorite-smectite, quartz, talc + magnetite, and minor amphibole, plus sulfide minerals, although relict olivine is present in some of the least altered rocks. Plagioclase is slightly altered to albite-oligoclase, and pyroxene is partly altered to amphibole with magnetite blebs. Amphiboles range from actinolite to magnesiohornblende in subequal amounts. The igneous titanomagnetite contains ilmenite exsolution lamellae and is partly to totally altered to titanite. Serpentine and a single occurrence of pumpellyite were reported in initial shipboard observations of the lower dikes (Dick, Erzinger, Stokking, et al., 1992; Alt, Kinoshita, Stokking, et al., 1993), but these identifications have not been confirmed in shorebased studies.

Veins are common, and consist of several types. Amphibole \pm chlorite veins and chlorite veins are by far the most common and occur as multiple generations of mutually crosscutting veins, commonly containing accessory titanite and apatite. Secondary clinopyroxene also occurs with amphibole in a few veins (Alt et al., 1995; Laverne et al., 1995; Vanko et al., this volume). Rare epidote, quartz, or quartz + epidote veins cut across both amphibole and chlorite veins, consistent with sequences in the upper dikes. Rare vein types include the following: one vein of quartz + chlorite + actinolite, anhydrite cutting a quartz + epidote vein, and rare crosscutting veins of late prehnite and laumontite (Alt, Kinoshita, Stokking, et al., 1993). Vein amphiboles range in composition from actinolite to magnesiohornblende, in some cases with actinolite at the center and hornblende along the edges (Alt et al., 1995; Laverne et al., 1995; Tartarotti et al., 1995; Vanko et al., this volume). In general, amphiboles are more actinolitic in veins than in the adjacent alteration halo, where actinolitic hornblende and magnesiohornblende are more common.

Light-colored alteration halos are common around amphibole \pm chlorite veins (Fig. 10). The halos range from a few millimeters up to $2 \mathrm{~cm}$ wide, and are more intensively recrystallized than the adjacent dark-gray host rock $(30 \%-100 \%$ vs. $10 \%-40 \%$, respectively). Olivine in the alteration halos is completely replaced by chlorite and amphibole. The sodic rims and mantles of igneous plagioclase are commonly partly replaced by secondary calcic plagioclase, which generally makes up a few percent (mostly $<5 \%$ ) of the rock. This secondary plagioclase mostly ranges from labradorite to anorthite $\left(\mathrm{An}_{75}-\mathrm{An}_{95}\right)$, and is consistently more calcic than the igneous plagioclase that it replaces (Laverne et al., 1995; Vanko et al., this volume). Patches and veins of albite-oligoclase, laumontite, and chlorite also replace igneous plagioclase and cut the secondary calcic plagioclase, leading to the presence of subequal amounts of sodic and calcic secondary plagioclase. Pyroxene is extensively to completely replaced by amphibole, and titanomagnetite is strongly to totally altered to ti- tanite. Amphiboles in alteration halos range from actinolite to magnesiohornblende, with the latter about twice as abundant as the former (Laverne et al., 1995; Vanko et al., this volume).

The rocks commonly exhibit irregularly shaped $1-$ to $10-\mathrm{cm}-$ sized, lighter colored alteration patches, where the rock is intensively recrystallized ( $40 \%-100 \%$; Fig. 10). The mineralogy of these patches is similar to the halos around veins, but the patches are unrelated to veins. Some of these patches clearly formed around primary pore space, where 1- to 5-mm-sized former vugs are now filled with chlorite, actinolite, epidote, laumontite, and/or anhydrite. Similar features are observed in the upper dikes and the patches probably represent more extensive hydrothermal reaction around locally enhanced primary pore spaces (Alt et al., 1985a, 1989b, 1995, this volume; $\mathrm{Zu}-$ leger et al., 1995; Bach et al., this volume). The light-colored intensively altered vein halos and patches comprise $\sim 10 \%$ of the core from the lower dikes (Dick, Erzinger, Stokking, et al., 1992; Alt, Kinoshita, Stokking, et al., 1993).

Besides the small (centimeter) scale effects of variable fluid access to the rocks, such as alteration halos and patches, the lower dikes display larger scale effects of varying fluid access. From 1710 to 1740 mbsf relict olivine is common and talc + magnetite partly replace olivine; it is inferred that this interval was relatively unfractured, which restricted seawater access and limited hydrothermal alteration. This interval corresponds to relatively low porosity from the resistivity log (e.g., Fig. 9; Pezard et al., this volume), consistent with this interpretation. Epidote, quartz, prehnite, and anhydrite are more common from 1820 to 1840 mbsf than elsewhere in the lower dikes. This zone has a high porosity as indicated by the resistivity log (Fig. 9; Pezard et al., this volume), suggesting that this was a zone of more intense fracturing that allowed access of relatively late, evolved hydrothermal fluids and later seawater recharge (Alt, Kinoshita, Stokking, et al., 1993).

Amphibole is the most common secondary mineral present both in veins and replacing pyroxene within the rocks, and is particularly abundant in the alteration halos and patches. Figure 15 shows the dramatic increase of the modal abundance of amphibole and the general increase in the average percent alteration with depth in lower dikes. Amphiboles in the lower dikes range from actinolite to magnesiohornblende and to edenitic hornblende (Figs. 13, 14; Alt et al., 1995; Laverne et al., 1995; Tartarotti et al., 1995; Vanko et al., this volume). A limited data set suggested that the Ti content of amphibole ranged to higher values and that magnesiohornblende was more common in the lower dikes than the upper dikes (Alt et al., 1995, this volume). The combined data sets of all available analyses do not show clear trends in amphibole composition with depth in the dikes (Fig. 13). Magnesiohornblende becomes more common below about 1300 mbsf, although this is the depth at which the number of analyses increases greatly. Below 1900 mbsf, however, there is less scatter in the data and mean compositions may shift more toward hornblende (Fig. 13). Figures 13 and 14 present all amphibole analyses, including multiple analyses of individual crystals, so they do not necessarily represent the proportions of different amphibole types in the rocks. In any case, magnesiohornblende is the most abundant amphibole in alteration halos and patches (Laverne et al., 1995; Vanko et al., this volume). The $\mathrm{Ti}$ contents of amphibole appear to generally correlate with $\mathrm{Al}$, suggesting that this may be a temperature effect, but the site of amphibole formation may also influence its composition (e.g., compositional variations in precursor pyroxene, proximity to titanomagnetite that is breaking down).

Phyllosilicates in the lower dikes exhibit the same range in mineralogy and composition as in the upper dikes (Figs. 8, 11), again emphasizing the heterogeneity of alteration effects. There is no simple transition downward from smectite to chlorite, rather, the formation of these minerals in the dikes is probably controlled by kinetic effects (Laverne et al., 1995).

Epidote from the lower dikes exhibits the same compositions and patchy compositional zoning of individual crystals as does epidote 


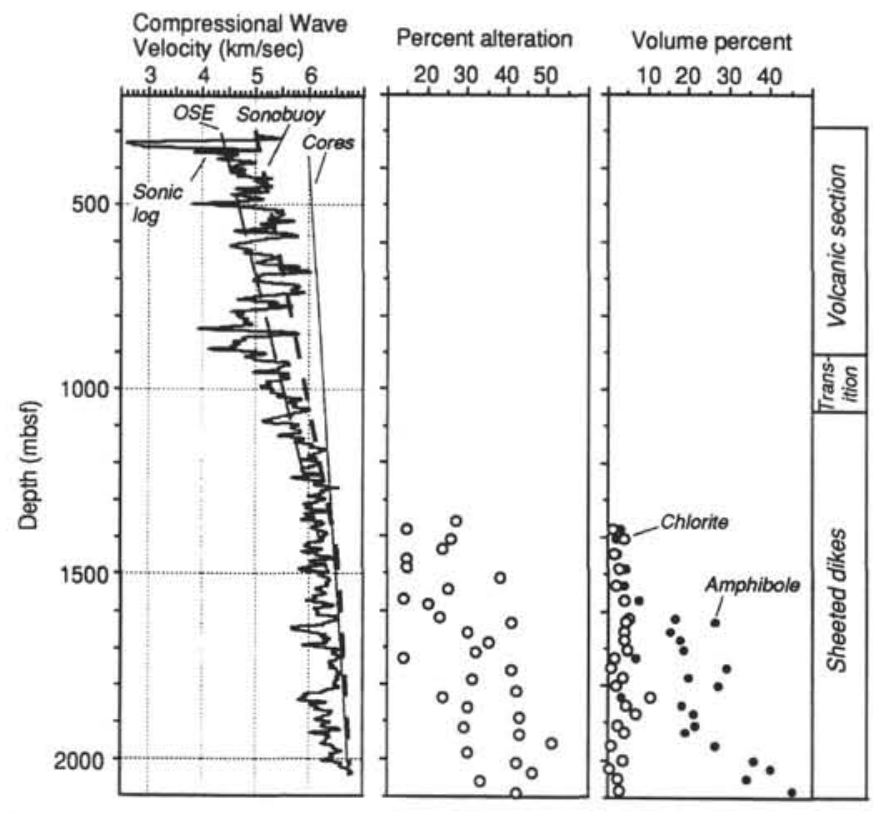

Figure 15. Compressional-wave velocities for Site 504 and alteration mineralogy vs. depth. Sonic log data (continuous profile), sonobuoy refraction profile from Collins et al. (1989; heavy dashed line), velocity profile from oblique seismic experiment (OSE) in Hole 504B (Little and Stephen, 1985; light dashed line), and best-fit line to $100 \mathrm{MPa}$ core measurements (fine solid line; Salisbury et al., this volume) all agree below $\sim 1400 \mathrm{mbsf}$. Percent alteration (modal percent total secondary minerals) and volume percent chlorite and amphibole from Alt, Kinoshita, Stokking, et al. (1993) and Alt et al. (this volume). See text for discussion.

from the upper dikes (Fig. 11). Prehnite from the lower dikes has generally lower $\mathrm{Fe} / \mathrm{Fe}+\mathrm{Al}$ than that from the upper dikes (Fig. 11), which may indicate that prehnites in the lower dikes formed at generally higher temperatures or lower oxygen fugacities than in the upper dikes (Liou et al., 1983).

Secondary clinopyroxene in the lower dikes occurs as colorless to green granular to fibrous to euhedral crystals, up to $50 \mu \mathrm{m}$ across. It occurs in nine samples and replaces and forms overgrowths on magmatic clinopyroxenes along veins and in alteration patches, and occurs with hornblende in veins filled with actinolite and chlorite (Alt et al., 1995; Laverne et al., 1995; Vanko et al., this volume). Secondary clinopyroxenes are mainly diopsidic in composition, and have higher $\mathrm{Ca}$ and $\mathrm{Fe}$ contents than magmatic clinopyroxenes (Fig. 16). Many of the secondary clinopyroxenes also have lower $\mathrm{Cr}$ and higher $\mathrm{Na}$ and in some cases $\mathrm{Ti}$ contents than igneous clinopyroxenes (Laverne et al. 1995, Vanko et al., this volume). Rare secondary augite occurs in the transition zone and upper dikes (at 959, 1436, and 1446 mbsf; Fig. 2; Laverne, 1987a; Ishizuka, 1989) and augite and Na-Tirich augite occur in veins in a few massive flows of the volcanic section (Fig. 2; Laverne, 1987b). Although uncertainties are quite large, temperatures estimated from pyroxene thermometry range to $>500^{\circ} \mathrm{C}$ (Laverne et al., 1995; Vanko et al., this volume). Some of these pyroxenes in the lower dikes could be related to early, high-temperature $\left(>400^{\circ} \mathrm{C}\right)$ alteration and formation of hornblende and calcic secondary plagioclase (see below), but others may be related to intrusion (or extrusion, in the case of massive flows) and initial penetration of fluids into the still hot, cooling rocks.

Figure 17 shows the compositions of secondary plagioclase from Hole 504B. Secondary plagioclase in the transition zone and upper dikes is restricted to albite and oligoclase $\left(\angle A n_{30}\right)$, whereas secondary plagioclase in the lower dikes ranges from early calcic plagioclase to late albite and oligoclase. All secondary plagioclases are generally

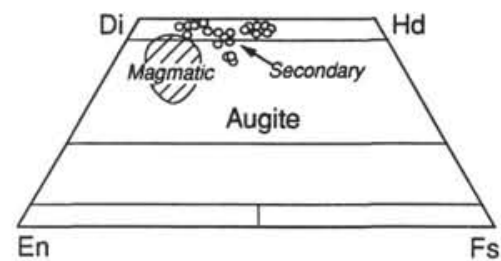

Figure 16. Compositions of secondary clinopyroxenes from the sheeted dikes of Hole 504B. Field of primary clinopyroxenes shown for comparison. Data from Laverne et al. (1995) and Vanko et al. (this volume).

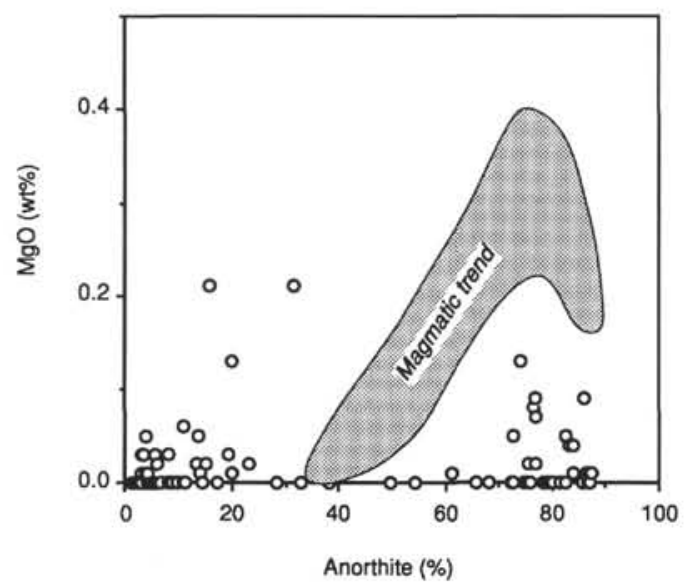

Figure 17. Compositions of secondary plagioclase from Hole 504B. Field of magmatic plagioclase shown for comparison. Secondary plagioclase in the upper dikes is restricted to albite and oligoclase $\left(\angle \mathrm{An}_{30}\right)$ whereas secondary plagioclase in the lower dikes ranges from early calcic plagioclase to late albite and oligoclase. All secondary plagioclases are generally depleted in $\mathrm{Mg}$ and Fe relative to magmatic plagioclase. Data from Alt et al. (1985a), Laverne (1987a), Ishizuka (1989), Laverne et al. (1995), and Vanko et al. (this volume).

depleted in $\mathrm{MgO}$ and $\mathrm{Fe}_{2} \mathrm{O}_{3}{ }^{\mathrm{T}}$ relative to magmatic plagioclase (Ishizuka, 1989; Laverne et al., 1995; Vanko et al., this volume).

\section{Alteration Processes}

The lower dikes underwent an early high-temperature alteration stage $\left(\geq 400^{\circ} \mathrm{C}\right)$, which preceded the alteration sequence outlined previously for the upper dikes, and which is consistent with predictions for subsurface reaction zones where hydrothermal fluids venting at the seafloor acquire their final chemical characteristics. The sequence and conditions of alteration in the lower dikes of Hole 504B have been divided into five stages on the basis of secondary mineral relationships in veins and host rocks, and from mineral chemical and isotopic data (Alt et al., 1995, this volume; Laverne et al., 1995; Tartarotti et al., 1995; Vanko et al., this volume).

1. The first stage occurred at high temperatures, $\geq 400^{\circ} \mathrm{C}$. Access of fluids to the rocks exerted a strong control on restricting the effects of this stage to veins, associated alteration halos, and alteration patches. Secondary clinopyroxene formed locally in veins. Hornblende and calcic secondary plagioclase formed in alteration halos and patches. Although the uncertainties are large, temperature estimates from pyroxene compositions and assuming calcic plagioclase-hornblende equilibria suggest temperatures of greater than $400^{\circ} \mathrm{C}$ for this alteration stage (Laverne et al., 1995; Vanko et al., this volume). The presence of secondary calcic plagioclase and the high estimated temperatures of alteration are consistent with experimental and theoreti- 
cal predictions of reactions within axial reaction zones, inferred to be 1-2 km sub-basement. Berndt et al. $(1988,1989)$ and Berndt and Seyfried (1993) suggest that calcium-enriched hydrothermal fluids are likely to be equilibrated with a calcic plagioclase (labradorite) at $400^{\circ} \mathrm{C}, 400$ bars, and that rocks in the reaction zone are only partly recrystallized. Other chemical and mineral effects in the lower dikes are also consistent with the reaction zone interpretation (see below).

2. Pervasive alteration occurred throughout the lower dikes at temperatures of up to $\sim 350^{\circ}-400^{\circ} \mathrm{C}$, but the most intense recrystallization occurred where fluids had more efficient access to the rocks (i.e., in alteration halos and patches). Actinolitic amphibole, chlorite, titanite, albite, and oligoclase formed in the rocks, perhaps with actinolitic hornblende and oligoclase reflecting higher temperatures than the chlorite + albite assemblage. The $\mathrm{Sr}$ isotopic compositions of hydrothermal fluids during the first two alteration stages listed here were rock dominated and variable (Alt et al., this volume). These first two stages are separated by mineralogical differences, but probably represent a continuum of changing conditions. The formation of mixed-layer clays and smectite are probably related to subsequent alteration at still lower temperatures, but may also reflect kinetic effects, with the amount of fracturing and access of fluids controlling the extent of recrystallization (Laverne et al., 1995). Where fluid access to the rocks was minimal, the assemblage talc + magnetite partly to totally replaced olivine in the rocks. This latter alteration could have taken place over a wide range of temperatures, up to as high as $500^{\circ}-600^{\circ} \mathrm{C}$ during initial penetration of fluids into the cooling dikes, and could be analogous to Stage 1 alteration described above.

3. Quartz and epidote formed in crosscutting veins locally within the rocks. Epidote and quartz in the lower dikes formed at temperatures of $310^{\circ}-350^{\circ} \mathrm{C}$ from ${ }^{18} \mathrm{O}$ enriched fluids ( 1\% ; Alt et al., 1995). The similarity in compositions, occurrence, and $\mathrm{Sr}$ and $\mathrm{O}$ isotopic compositions of epidotes from the lower dikes to those from $800 \mathrm{~m}$ shallower in the transition zone, and the association of epidote in the transition zone with sulfide mineralization suggests that epidote + quartz veins record the presence of upwelling high-temperature hydrothermal fluids at Site 504 (Alt et al., this volume). Epidote veins are rare in the lower dikes, however, in contrast to the common epidote veins in the uppermost dikes and lower transition zone.

4. The formation of anhydrite locally in the lower dikes was originally interpreted to reflect heating of seawater during relatively late recharge of seawater into the dikes as in the upper dike section (Alt et al., 1989b, 1995; Dick, Erzinger, Stokking, et al., 1992; Laverne et al., 1995). Low $\delta^{34} \mathrm{~S}$ values for anhydrite $(11 \%$ ) have since been reinterpreted, however, and it is suggested that they are consistent with incorporation of oxidized basaltic sulfide into sulfate-bearing hydrothermal fluids under relatively oxidizing conditions in the subsurface reaction zone (Seyfried and Ding, 1993; Alt, 1995). Anhydrite in rare crosscutting veins and at the centers of zoned vugs is consistent with a late origin for anhydrite, but the sulfur isotopic data indicate more reacted fluid compositions in the lower dikes.

5 . Laumontite and prehnite formed locally at temperatures less than about $250^{\circ} \mathrm{C}$, and reactions are interpreted to have occurred during continued circulation of more evolved (Mg-depleted, Ca-enriched) off-axis hydrothermal fluids (Alt et al., 1986a; Laverne et al., 1995; Vanko et al., this volume). Although the mineralogy and inferred conditions for this stage are the same in the lower as in the upper dikes, these minerals are rare and only occur in trace amounts in the lower dikes, in contrast to their much greater abundance in the upper dikes. Late veins in general are rare in the lower dikes, indicating that permeability and off-axis circulation was much more restricted in the lower dikes compared to the upper dikes and transition zone.

The alteration stages are generally similar in the upper and lower dikes, and the temperatures of alteration in these two zones overlapped significantly. However, the peak alteration temperatures were greater in the lower dikes, and more of the alteration in the lower dikes took place at higher temperatures as indicated by secondary mineralogy, mineral chemistry, the intensity of recrystallization of the rocks, and whole-rock chemical changes (see below).

The present temperature in Hole 504B increases with depth to $189^{\circ} \mathrm{C}$ at $2000 \mathrm{mbsf}$ (Guerin et al., this volume). There is no evidence that the rocks in the lower $600 \mathrm{~m}$ of the sheeted dikes have ever been cooler than the currently measured $160^{\circ}-190^{\circ} \mathrm{C}$ over this depth interval. Gu and Vanko (this volume) speculate that the lower dikes could have cooled and then been reheated to the present temperatures, although no data are given to support this.

\section{Bulk-Rock Chemical Changes}

The primary compositions of the lower dikes are similar to those in the rest of the section. Covariations in $\mathrm{Mg}$ number, $\mathrm{Cr}, \mathrm{Ni}, \mathrm{Sr}$, $\mathrm{TiO}_{2}, \mathrm{SiO}_{2}, \mathrm{Y}$, and $\mathrm{Zr}$ in the lower dikes are the results of $<50 \%$ fractionation and crystallization from a primary melt (Zuleger et al., 1995; Bach et al., this volume). Cyclic variations of these elements with depth in the lower dikes are suggested to be the result of injection of packets of dikes having similar compositions (Zuleger et al., 1995). Cyclic variations in grain size within the lower dikes are also interpreted to reflect this process (Dick, Erzinger, Stokking, et al., 1992; Umino, 1995).

Probably the most significant chemical changes in the lower dikes are the losses of $\mathrm{Cu}, \mathrm{Zn}$, and S (Fig. 5). These are the results of breakdown of sulfide minerals and titanomagnetite at high alteration temperatures $\left(>350^{\circ} \mathrm{C}\right)$, where the solubility of metals and sulfide in hydrothermal fluids increases significantly (Seyfried et al., 1991; Seewald and Seyfried, 1990; Alt et al., 1995, this volume; Zuleger et al., 1995; Bach et al., this volume). These effects are consistent with the lower dike section being part of a subsurface reaction zone that supplies metals and sulfur to hydrothermal fluids that vent at black smokers on the seafloor. Mass-balance calculations indicate that the amounts of $\mathrm{Zn}$ and $\mathrm{Cu}$ lost from the lower dikes can account for the increases of these elements in the mineralized transition zone (Fig. 5; Zuleger et al., 1995).

Slightly elevated whole-rock $\delta^{34} \mathrm{~S}$ values and local S-enrichments in the lower dikes are the results of formation of anhydrite in pores in the rocks (Fig. 6; Alt et al., 1995). Some samples exhibit $\mathrm{CaO}$ decreases and elevated $\mathrm{Na}_{2} \mathrm{O}$ and slight positive Eu anomalies as the results of albitization of calcic plagioclase (Zuleger et al., 1995). Otherwise bulk chemical changes are relatively small: slight increases of $\mathrm{H}_{2} \mathrm{O}$ and $\mathrm{CO}_{2}$ and losses of $\mathrm{K}$ and $\mathrm{Li}$ are apparent (Fig. 5). The loss of $\mathrm{Li}$ from the lower dikes is in contrast to the retention of $\mathrm{Li}$ in the upper dikes and slight gains of $\mathrm{Li}$ in the transition zone, and probably reflects the higher temperatures of alteration in the lower dikes. There is scatter of $\mathrm{TiO}_{2}$ to low values and of $\mathrm{P}_{2} \mathrm{O}_{5}$ to both higher and lower values, reflecting limited mobilization of these elements from the rocks to form titanite and apatite in adjacent veins.

Whole-rock $\delta^{18} \mathrm{O}$ values continue the progressive decrease downward in the lower dikes (Fig. 6), consistent with greater intensities of recrystallization and higher alteration temperatures with depth (Agrinier et al., 1995; Alt et al., 1995, this volume). In contrast to the upper dikes, alteration halos and patches in the lower dikes tend to have lower $\delta^{18} \mathrm{O}$ values than adjacent host rocks. This reflects both the higher alteration temperatures and a general lack of superimposed lower temperature alteration effects $\left({ }^{18} \mathrm{O}\right.$ enrichment of previously ${ }^{18} \mathrm{O}$ depleted rocks) in the lower dikes (Alt et al., 1995; this volume).

Similar to the upper dikes, there is no consistent enrichment of $\mathrm{Mg}$ in the lower dikes. This reflects a combination of factors: although analyzed bulk rocks are not enriched in $\mathrm{Mg}$, there may be a net uptake of $\mathrm{Mg}$ by the crust in veins and dike margin breccias (Alt et al., 1986a); Mg uptake was kinetically inhibited, i.e., the rocks are only partly recrystallized; and hydrothermal fluids may have been depleted in $\mathrm{Mg}$ through prior reactions at shallower depths. The lower dikes exhibit low whole-rock ${ }^{87} \mathrm{Sr} /{ }^{86} \mathrm{Sr}$ ratios as the result of low integrated seawater/rock ratios and the presence of rock-dominated fluids having low ${ }^{87} \mathrm{Sr} /{ }^{86} \mathrm{Sr}$ ratios (Fig. 6; Alt et al., this volume). In contrast, the 
transition zone and upper dikes exhibit scatter to much higher values as the result of interaction with seawater in the subsurface mixing zone.

\section{THE LAYER 2/3 TRANSITION AT SITE 504}

Whereas some physical properties (thermal conductivity and bulk density) measured on core samples do not exhibit any trends between upper and lower dikes, other properties exhibit significant changes with depth (Anderson, Honnorez, Becker, et al., 1985; Becker, Sakai, et al., 1988; Dick, Erzinger, Stokking, et al., 1992; Alt, Kinoshita, Stokking, et al., 1993). Porosity measured on core samples decreases in the dike section, from an average of $1.8 \%$ in the upper dikes above $1500 \mathrm{~m}$ to $0.7 \%$ below this depth. The resistivity log also indicates a general decrease in porosity downward in the dikes, from about $1 \%$ at the top to near zero at the base of the hole (Pezard et al., this volume). Compressional-wave velocities measured in samples on board ship show a decrease from the upper to the lower dikes, but this is caused by opening of microcracks in the samples decreasing the 1 atmosphere measurement values. Velocities measured on cores at 100 MPa confining pressure exhibit an increase downward, from $<6.5$ $\mathrm{km} / \mathrm{s}$ in the upper dikes to $\sim 6.5 \mathrm{~km} / \mathrm{s}$ in the lower dikes (below $\sim 1400$ mbsf; Iturrino, 1995; Salisbury et al., this volume). The sonic velocity $\log$ also indicates increasing velocities downward in the dikes, from $5.5 \mathrm{~km} / \mathrm{s}$ at the top of the sheeted dikes at $1100 \mathrm{mbsf}$ to values of $6.5 \mathrm{~km} / \mathrm{s}$ somewhere between $1500 \mathrm{mbsf}$ and $1700 \mathrm{mbsf}$, and reaching a maximum of $6.8 \mathrm{~km} / \mathrm{s}$ at $2060 \mathrm{mbsf}$ (Fig. 15). Velocities determined using the vertical seismic profile (VSP) closely follow the trend of those from the sonic log, but the VSP velocities are generally equal to the highest $\log$ values (Swift et al., this volume). Similarly, the high-pressure core velocities fall at the high end of the log velocities (Fig. 15). These discrepancies are interpreted to reflect the presence of drilling-induced fractures which decrease the log velocities (Salisbury et al., this volume), an interpretation supported by the electrical logs (Ayadi et al., this volume; Pezard et al., this volume).

The velocities determined by the VSP, the sonic log, and the highpressure core measurements are generally consistent with velocities determined from seismic refraction experiments (Fig. 15). Detrick et al. (1994) reevaluated available seismic data for the Site 504 area and suggest that the Layer 3 velocity at Site 504 is $6.5 \mathrm{~km} / \mathrm{s}$, somewhat lower than the typical $6.7 \mathrm{~km} / \mathrm{s}$ of Layer 3, but still within the range of Layer 3 velocities. These authors interpret that the transition from Layer 2 to Layer 3 occurs at $1500 \pm 200$ mbsf in Hole 504B, where velocities reach $6.5 \mathrm{~km} / \mathrm{s}$ and the gradient flattens (Fig. 15). Salisbury et al. (this volume) compiled shipboard modal data for core samples, and showed that the abundance of amphibole increases at the expense of clinopyroxene, and chlorite abundance decreases with depth in the dikes. The total percent alteration of the rocks also increases in the lower dikes (Fig. 15). Salisbury et al. (this volume) suggest that because $V p_{\text {cp }}>V p_{\text {actinolite }} \gg V p_{\text {plagioclase }} \gg V p_{\text {chlorite }}$, the change in hydrothermal alteration effects with depth can cause increased velocities up to typical Layer 3 values as chlorite abundance goes to near zero at $\sim 2000$ mbsf; that is, the Layer $2 / 3$ transition can be thought of as a metamorphic transition. Alternatively, these authors indicate that if the Layer $2 / 3$ transition is defined as the inflection point on the velocity depth curve at about 1500 mbsf, then the downward decrease in porosity at this depth can account for the transition. In contrast, on the basis of the increase in velocities across the transition zone determined by the VSP, Swift et al. (this volume) place the Layer $2 / 3$ transition at the top of the dikes at $\sim 1000$ mbsf. These authors suggest that the discrepancy between the depths to Layer 3 as determined by the VSP and refraction studies is the result of the scale of observation: that refraction studies average structure over a kilometer scale, whereas the VSP measurements are made on a scale of $\sim 200 \mathrm{~m}$. They also point out that the sonic $\log$ and core measurements are made at a much smaller scale of $<2 \mathrm{~m}$, so that core and $\log$ measurements will not necessarily agree with the VSP measurements. As the seismic layering of the ocean crust is defined by refraction studies, it seems most reasonable to place the Layer $2 / 3$ boundary at about $1500 \mathrm{mbsf}$, presumably at the approximate middle of the sheeted dikes, where significant changes in physical properties (decreased porosity, increased sonic velocities) as well as mineralogical and chemical effects of hydrothermal alteration (increasing amphibole and decreasing chlorite abundances, decreasing plagioclase alteration) occur in the core.

\section{FRACTURING AND FAULTING AT THE BASE OF HOLE 504B}

Certainly one of the most significant results of drilling in Hole 504B on Leg 148 was that the drill string became stuck at $2111 \mathrm{mbsf}$, ultimately causing abandonment of drilling operations in the hole (Alt, Kinoshita, Stokking, et al., 1993). Flat, platy-shaped rock fragments are common in Leg 148 cores, but were not recovered in shallower cores. The surfaces of these fragments are steeply dipping fractures that exhibit steps and lineations, and are interpreted to be microfaults. The penetration rate for the last core (2103.5-2111.0 mbsf) was very fast ( $7 \mathrm{~m} / \mathrm{hr}$, compared to about $1 \mathrm{~m} / \mathrm{hr}$ for the rest of the section), and it is in this zone that the drill string became stuck. The extremely high penetration rate for this core and the interpretation of fracturing and slickenlines on the tabular rock pieces as microfaults suggested that Leg 148 passed through a zone of microfaults that led up to penetration of pulverized material in a fault at 2104 2111 mbsf (Alt, Kinoshita, Stokking, et al., 1993). Although it is still a reasonable interpretation that Leg 148 became stuck in a fault zone, evidence from electrical logs and reevaluation of "microfaults" suggest that the "microfaults" were induced during drilling (Dilek et al., this volume; Pezard et al., this volume).

Morin et al. (1990) show that the azimuth of major borehole elongation from breakouts in the upper dikes lies approximately $120^{\circ} \mathrm{N}$, parallel to the minimum horizontal stress direction at Site 504. Secondary breakouts parallel to $015^{\circ} \mathrm{N}$ are caused by thermal stresses resulting from cooling of the borehole during drilling. Toward the bottom of the dikes the borehole elongation is parallel to steeply dipping, open fractures in the borehole walls, both of which trend $015^{\circ} \mathrm{N}$ (Ayadi et al., this volume; Pezard et al., this volume). Resistivity logs indicate subvertical fracture porosity in the borehole walls at 19752005 mbsf, the same interval at which the fractures are abundant in the borehole walls (Ayadi et al., this volume; Pezard et al., this volume). Pezard et al. (this volume) suggest that, because this interval coincides with the depth where drilling was begun on Leg 148 and breakouts and fractures are parallel to thermally induced breakouts at shallower depths, cooling of the borehole before drilling on Leg 148 caused the fracturing at 1975-2005 mbsf.

There is abundant evidence for drilling-induced fracturing in core recovered from the lower dikes, including common core disking fractures and centerline fractures which indicate high in situ stresses (Alt, Kinoshita, Stokking, et al., 1993). Paleomagnetically oriented centerline fractures strike $133^{\circ} \mathrm{N}$ (Dick, Erzinger, Stokking, et al., 1992), close to the minimum horizontal stress direction at Site 504. The microfaults in Leg 148 core are open, unmineralized, and lack any displacement. Moreover, the microfaults were recovered from an interval in the hole that displays the highest sonic velocities and lowest resistivities, indicating that the borehole walls are unfractured (2026-2052 mbsf). The combined evidence for drilling-induced fracturing in core from the lower dikes and the lack of fracturing in the borehole walls at the depths where microfaults were recovered suggests that the microfaults are drilling-induced fractures (Dilek et al., this volume; Pezard et al., this volume). 


\section{COMPARISON TO HYDROTHERMAL EFFECTS IN OPHIOLITES}

Many features of hydrothermal alteration in the sheeted dikes from Hole 504B are similar or analogous to those seen in ophiolites. For example, a steep temperature gradient downward across the transition from volcanic rocks to dikes is observed in the Troodos ophiolite, as in Hole 504B (Gillis and Robinson, 1990). The transition zone and uppermost dikes in ophiolites also commonly exhibit disseminated sulfide mineralization with corresponding enrichments of metals and sulfur, similar to that in Hole 504B, suggesting that this effect may be characteristic of ophiolitic and oceanic crust (Harper et al., 1988; Gillis and Robinson, 1990; Alt, 1994, 1995; Nehlig et al., 1994). In some ophiolites there is a change from predominantly actinolite to increasing amounts of hornblende with depth in the dikes (Harper et al., 1988; Pflumio, 1991), and whereas actinolite is absent in the uppermost dikes of the Troodos ophiolite, it is characteristic of the lower dikes (Baragar et al., 1989; Gillis and Robinson, 1990; Alt, 1994). The concentrations of metals and sulfur also exhibit a general decrease in the lower dikes of the Troodos and Josephine ophiolites, similar to Hole 504B (Harper et al., 1988; Baragar et al., 1989; Alt, 1994).

In contrast, several features of hydrothermal alteration in ophiolites differ significantly from Hole 504B. The volcanic sections of ophiolites are commonly more completely recrystallized and altered at higher grades than Hole 504B and other oceanic volcanic sections, with the ophiolitic rocks commonly containing phases such as albite \pm prehnite \pm pumpellyite, which are rare or absent in oceanic volcanic rocks (Harper et al., 1988; Pflumio, 1991; Schiffman et al., 1991). These effects may in part be the result of sealing by a thick sedimentary cover and a lack of focused fluid flow along faults in the ophiolites (Schiffman et al., 1991), but probably also reflect such effects as multiple periods of intrusive and volcanic activity as well as superimposed regional metamorphic effects in the ophiolites. Differences in primary compositions and mineralogy of volcanic rocks in ophiolites and ocean crust could also cause differences in the intensity of recrystallization. Similarly, the sheeted dikes in ophiolites are typically completely recrystallized, whereas dikes from Hole 504B (and elsewhere from oceanic crust) are characteristically only partly recrystallized (Gillis and Robinson, 1990; Gillis and Thompson, 1993; Alt, 1994).

Secondary calcic plagioclase and abundant millimeter-scale amphibole veins are unknown and uncommon, respectively, in ophiolites. In the Oman ophiolite, Nehlig and Juteau (1988) described only epidote + quartz veins in sheeted dikes, whereas amphibole veins are confined to the gabbroic units. In the Josephine ophiolite, Alexander et al. (1993) described hornblende-bearing veins in the transition zone from the sheeted dikes to the underlying gabbros, with veins in the gabbro more abundant than in the dike complex. Amphibole veins are, however, common in the lower sheeted dikes of the Troodos ophiolite (K. Gillis, pers. comm., 1995). Finally, epidote is much more abundant in ophiolites than in Hole 504B, and epidosites (e.g., Richardson et al., 1987; Schiffman et al., 1987) are absent in Hole 504B and in oceanic sample suites altogether. Epidosites represent deep upflow zones where large volumes of hydrothermal fluids were focused into upflow, in contrast to the lower sheeted dikes from Hole $504 \mathrm{~B}$, which represent a region where integrated water/rock ratios were low and hydrothermal recrystallization and chemical and isotopic exchange were limited by fluid access.

\section{CONCLUSIONS}

Hole 504B has reached $2111 \mathrm{mbsf}$, penetrating through $274.5 \mathrm{~m}$ sediment, $571.5 \mathrm{~m}$ of volcanic rocks, a $209 \mathrm{~m}$ transition zone, and $1050 \mathrm{~m}$ into a sheeted dike complex. Deeper penetration was prevented when the drill string became stuck in an inferred fault zone at the bottom of the hole. The volcanic section was altered through a series of processes involving interaction with seawater at low temperatures, with the effects of cold, oxidizing seawater decreasing downward. These processes and their resultant effects on the volcanic section apparently fall within the ranges that are typical of upper oceanic crust (Alt, in press).

The transition zone and upper dikes were altered in a subsurface mixing zone, where hydrothermal fluids upwelling through the dikes mixed with cooler seawater solutions circulating in the overlying more permeable volcanic rocks. As a result the transition zone exhibits disseminated metal sulfide mineralization, similar to many ophiolites, and this effect may be typical of ocean crust. Alteration of the transition zone and upper dikes occurred in a series of stages, reflecting the thermal and chemical evolution of the hydrothermal system: from (1) early chlorite, actinolite, albite-oligoclase, and titanite, to (2) quartz, epidote and sulfides, to (3) anhydrite, and finally to (4) zeolites and local calcite. The maximum temperature estimated for the first two stages is $350^{\circ}-380^{\circ} \mathrm{C}$, and the inferred mineral assemblages for these early stages are typical of the greenschist facies.

The lower dikes underwent an early, high-temperature $\left(\geq 400^{\circ} \mathrm{C}\right)$ alteration stage, with the formation of hornblende and calcic secondary plagioclase locally in alteration halos and patches. The temperatures and reaction products are consistent with inferred conditions in deep subsurface reaction zones, where hydrothermal vent fluids acquire their final compositions. Much of the subsequent reactions produced greenschist assemblages at $\sim 300^{\circ}-400^{\circ} \mathrm{C}$. The lower dikes have lost metals and S and are a source of these elements to hydrothermal vent fluids and seafloor sulfide deposits. The lower dikes underwent subsequent alteration stages similar to the upper dikes, with rare epidote + quartz veins recording the presence of upwelling hydrothermal fluids, and limited late off- axis effects (zeolites and prehnite). Anhydrites in the lower dikes indicate more reacted fluid compositions than in the upper dikes.

Alteration of the sheeted dikes from Hole 504B is heterogeneous. Fracturing and its effect on permeability and access of fluids are important controls on alteration, and throughout most of the dikes alteration was kinetically limited. Recrystallization is most intense along fractures and areas of enhanced primary pore space in the rocks, and in local highly fractured zones. The transition zone is highly fractured and altered, and the amount of alteration increases downward in the lower dikes, probably as the result of higher alteration temperatures at the base of the dikes.

The alteration stages in the dikes have been fit to steady-state processes occurring as the crust moved off axis, away from the axis of spreading and magma injection (Alt et al., 1985, 1986a). These hydrothermal stages could just as well have all occurred at the axis, as a magmatically driven hydrothermal system went through a cycle of waning intensity caused by solidification and cooling of an intermittent magma chamber, with periodic intrusion of cold seawater to form anhydrite in the cooling system. Alternatively, these stages could reflect multiple episodes of hydrothermal activity, from different sites of magma injection along the axis; for example, the first three stages resulting from a proximal heat source and then waning of activity and seawater recharge, followed by the fourth stage as the result of hydrothermal activity from a more distal heat source along the axis. Whatever the case, the rocks record the effects of thermal and chemical evolution of the hydrothermal system. Variations in the details of alteration of other sections of upper crust from that observed in Hole 504B are to be expected as the results of differing fracturing patterns and heat sources (e.g., Alt et al., this volume).

Reevaluation of existing geophysical data combined with new measurements show that Hole 504B was already in Layer 3 or within the transition to Layer 3 before drilling during Leg 148. This may have answered the geophysical question of what the Layer $2 / 3$ boundary in the ocean crust really is (at least at Site 504). However, the major petrological questions of what the transition from sheeted dikes to gabbros is like within in situ ocean crust and what the uppermost gab- 
bros look like petrologically remain unanswered. Also, the nature of the inferred fault at the base of Hole 504B and its role in fluid flow and alteration are unknown.

\section{ACKNOWLEDGMENTS}

This work was supported by grants from JOI-USSAC and by NSF Grant No. OCE 9217423 and OCE 9314218 to J. Alt, and by grants from CNRS-INSU to J. Honnorez and C. Laverne. We thank Kathryn Gillis and Susan Humphris for helpful reviews.

\section{REFERENCES}

Adamson, A.C., 1985. Basement lithostratigraphy, Deep Sea Drilling Project Hole 504B, In Anderson, R.N., Honnorez, J., Becker, K., et al., Init. Repts. DSDP, 83: Washington (U.S. Govt. Printing Office), 121-127.

Agar, S.M., 1991. Microstructural evolution of a deformation zone in the upper ocean crust: evidence from DSDP Hole 504B. J. Geodyn., 13:119140.

Agrinier, P., Laverne, C., and Tartarotti, P., 1995. Stable isotope ratios (oxygen, hydrogen) and petrology of hydrothermally altered dolerites at the bottom of the sheeted dike complex of Hole 504B. In Erzinger, J., Becker, K., Dick, H.J.B., and Stokking, L.B. (Eds.), Proc. ODP, Sci. Result., 137/140: College Station, TX (Ocean Drilling Program), 99-106.

Alexander, R.J., Harper, G.D., and Bowman, J.R., 1993. Oceanic faulting and fault-controlled subseafloor hydrothermal alteration in the sheeted dike complex of the Josephine ophiolite. J. Geophys. Res., 98:97319760.

Alt, J.C., 1994. A sulfur isotopic profile through the Troodos ophiolite, Cyprus: primary composition and the effects of seawater hydrothermal alteration. Geochim. Cosmochim. Acta, 58:1825-1840.

-, in press. Subseafloor processes in mid-ocean ridge hydrothermal systems. In Humphris, S.E., Zierenberg, R., Mullineaux, L., and Thomson, R. (Eds.), Seafloor Hydrothermal Systems: Physical, Chemical, Biological and Geological Interactions within Hydrothermal Systems. Geophys. Monogr., Am. Geophys. Union.

1995. Sulfur isotopic profile through the oceanic crust: sulfur mobility and seawater-crustal sulfur exchange during hydrothermal alteration. Geology, 23:585-588.

Alt, J.C., Anderson, T.F., and Bonnell, L., 1989a. The geochemistry of sulfur in a $1.3 \mathrm{~km}$ section of hydrothermally altered oceanic crust, DSDP Hole 504B. Geochim. Cosmochim. Acta, 53:1011-1023.

Alt, J.C., Anderson, T.F., Bonnell, L., and Muehlenbachs, K., 1989b. Mineralogy, chemistry, and stable isotopic compositions of hydrothermally altered sheeted dikes: ODP Hole 504B, Leg 111. In Becker, K., Sakai, H., et al., Proc. ODP, Sci. Results, 111: College Station, TX (Ocean Drilling Program), 27-40.

Alt, J.C., and Emmermann, R., 1985. Geochemistry of hydrothermally altered basalts: Deep Sea Drilling Project Hole 504B. In Anderson, R.N., Honnorez, J., Becker, K., et al., Init. Repts. DSDP, 83: Washington (U.S. Govt. Printing Office), 249-262.

Alt, J.C., Honnorez, J., Laverne, C., and Emmermann, R., 1986a. Hydrothermal alteration of a $1 \mathrm{~km}$ section through the upper oceanic crust, Deep Sea Drilling Project Hole 504B: mineralogy, chemistry, and evolution of seawater-basalt interactions. J. Geophys. Res., 91:10309-10335.

Alt, J.C., Kinoshita, H., Stokking, L.B., et al., 1993. Proc. ODP, Init. Repts., 148: College Station, TX (Ocean Drilling Program).

Alt, J.C., Laverne, C., and Muehlenbachs, K., 1985a. Alteration of the upper oceanic crust: mineralogy and processes in Deep Sea Drilling Project Hole 504B, Leg 83, In Anderson, R.N., Honnorez, J., Becker, K., et al., Init. Repts. DSDP, 83: Washington (U.S. Govt. Printing Office), 217247.

Alt, J.C., Muehlenbachs, K., and Honnorez, J., 1986b. An oxygen isotopic profile through the upper kilometer of the oceanic crust, DSDP Hole 504B. Earth Planet. Sci. Lett., 80:217-229.

Alt, J.C., Saltzman, E.S., and Price, D.A., 1985b. Anhydrite in hydrothermally altered basalts: Deep Sea Drilling Project Hole 504B, Leg 83. In Anderson, R.N., Honnorez, J., Becker, K., et al., Init. Repts. DSDP, 83: Washington (U.S. Govt. Printing Office), 283-288.

Alt, J.C., Zuleger, E., and Erzinger, J.A., 1995. Mineralogy and stable isotopic compositions of the hydrothermally altered lower sheeted dike com- plex, Hole 504B, Leg 140. In Erzinger, J., Becker, K., Dick, H.J.B., and Stokking, L.B. (Eds.), Proc. ODP, Sci. Results, 137/140: College Station, TX (Ocean Drilling Program), 155-166.

Anderson, R.N., Honnorez, J., Becker, K., Adamson, A.C., Alt, J.C., Emmermann, R., Kempton, P.D., Kinoshita, H., Laverne, C., Mottl, M.J., and Newmark, R.L., 1982. DSDP Hole 504B, the first reference section over $1 \mathrm{~km}$ through Layer 2 of the oceanic crust. Nature, 300:589-594.

Anderson, R.N., Honnorez, J., Becker, K., et al., 1985. Init. Repts. DSDP, 83: Washington (U.S. Govt. Printing Office).

Autio, L.K., and Rhodes, J.M., 1983. Costa Rica Rift Zone basalts: geochemical and experimental data from a possible example of multistage melting. In Cann, J.R., Langseth, M.G., Honnorez, J., Von Herzen, R.P., White, S.M., et al., Init. Repts. DSDP, 69: Washington (U.S. Govt. Printing Office), 729-745.

Autio, L.K., Sparks, J.W., and Rhodes, J.M., 1989. Geochemistry of Leg 111 basalts: intrusive feeders for highly depleted pillows and flows. In Becker, K., Sakai, H., et al., Proc. ODP, Sci. Results, 111: College Station, TX (Ocean Drilling Program), 3-16.

Auzende, J.-M., Bideau, D., Bonatti, E., Cannat, M., Honnorez, J., Lagabrielle, Y., Malavielle, J., Mamaloukas-Frangoulis, V., and Mevel, C., 1990. The MAR-Vema Fracture Zone intersection surveyed by deep submersible, Nautile. Terra Nova, 2:68-73.

Baragar, W.R.A., Lambert, M.B., Baglow, N., and Gibson, I.L., 1989. Sheeted dikes from CY-4 and surface sections: Troodos Ophiolite. In Gibson, I.L., Malpas, J., Robinson, P.T., and Xenophontos, C. (Eds.), Cyprus Crustal Study Project: Initial Report, Hole CY-4. Geol. Surv. Can., 69-106.

Barrett, T.J., 1983. Strontium- and lead-isotope composition of some basalts from Deep Sea Drilling Project Hole 504B, Costa Rica Rift, Legs 69 and 70. In Cann, J.R., Langseth, M.G., Honnorez, J., Von Herzen, R.P., White, S.M., et al., Init. Repts. DSDP, 69: Washington (U.S. Govt. Printing Office), 643-650.

Barrett, T.J., and Friedrichsen, H., 1982. Strontium and oxygen isotopic composition of some basalts from Hole 504B, Costa Rica Rift, DSDP Legs 69 and 70. Earth Planet. Sci. Lett., 60:27-38.

Becker, K., 1985. Large-scale electrical resistivity and bulk porosity of the oceanic crust, Deep Sea Drilling Project Hole 504B, Costa Rica Rift. In Anderson, R.N., Honnorez, J., Becker, K., et al., Init. Repts. DSDP, 83: Washington (U.S. Govt. Printing Office), 419-427.

Becker, K., Foss, G., et al., 1992. Proc. ODP, Init. Repts., 137: College Station, TX (Ocean Drilling Program).

Becker, K., Sakai, H., Adamson, A.C., Alexandrovich, J., Alt, J.C., Anderson, R.N., Bideau, D., Gable, R., Herzig, P.M., Houghton, S.D., Ishizuka, H., Kawahata, H., Kinoshita, H., Langseth, M.G., Lovell, M.A., Malpas, J., Masuda, H., Merrill, R.B., Morin, R.H., Mottl, M.J., Pariso, J.E., Pezard, P.A., Phillips, J.D., Sparks, J.W., and Uhlig, S., 1989. Drilling deep into young oceanic crust, Hole 504B, Costa Rica Rift. Rev. Geophys., 27:79-102.

Becker, K., Sakai, H., et al., 1988. Proc. ODP, Init. Repts., 111: College Station, TX (Ocean Drilling Program).

1989. Proc. ODP, Sci. Results, 111: College Station, TX (Ocean Drilling Program)

Berndt, M.E., Seyfried, W.E., and Beck, J.W., 1988. Hydrothermal alteration processes at mid-ocean ridges: experimental and theoretical constraints from $\mathrm{Ca}$ and $\mathrm{Sr}$ exchange reactions and $\mathrm{Sr}$ isotopic ratios. J. Geophys. Res., 93:4573-4583.

Berndt, M.E., and Seyfried, W.E., Jr., 1993. Ca and $\mathrm{Na}$ exchange during hydrothermal alteration of calcic plagioclase at $400^{\circ} \mathrm{C}$ and 400 bars. Geochim. Cosmochim. Acta, 57:4445-4451.

Berndt, M.E., Seyfried, W.E., Jr., and Janecky, D.R., 1989. Plagioclase and epidote buffering of cation ratios in mid-ocean ridge hydrothermal fluids: experimental results in and near the supercritical region. Geochim. Cosmochim. Acta, 53:2283-2300.

Bird, D.K., Schiffman, P., Elders, W.A., Williams, A.E., and McDowell, D., 1984. Calc-silicate mineralization in active geothermal systems. Econ. Geol., 79:671-695.

Bryan, W.B., Thompson, G., Frey, F.A., and Dickey, J.S., 1976. Inferred geologic settings and differentiation in basalts from the Deep Sea Drilling Project. J. Geophys. Res., 81:4285-4304.

Cann, J.R., Langseth, M.G., Honnorez, J., Von Herzen, R.P., White, S.M., et al., 1983. Init. Repts. DSDP, 69: Washington (U.S. Govt. Printing Office).

Christensen, N.I., and Salisbury, M.H., 1975. Structure and constitution of the lower oceanic crust. Rev. Geophys. Space Phys., 13:57-86. 
Collins, J.A., Brocher, T.M., and Purdy, G.M., 1989. Seismic-reflection structure of the upper oceanic crust: implications from DSDP/ODP Hole 504B, Panama Basin. In Becker, K., Sakai, H., et al., Proc. ODP, Sci. Results, 111: College Station, TX (Ocean Drilling Program), 177-191.

Detrick, R., Collins, J., Stephen, R., and Swift, S., 1994. In situ evidence for the nature of the seismic layer $2 / 3$ boundary in oceanic crust. Nature, 370:288-290.

Dick, H.J.B., Erzinger, J., Stokking, L.B., et al., 1992. Proc. ODP, Init. Repts., 140: College Station, TX (Ocean Drilling Program).

Emmermann, R., 1985. Basement geochemistry, Hole 504B. In Anderson, R.N., Honnorez, J., Becker, K., et al., Init. Repts. DSDP, 83: Washington (U.S. Govt. Printing Office), 183-199.

Fisher, A.T., Becker, K., and Narasimhan, T.N., 1994. Off-axis hydrothermal circulation: parametric tests of a refined model of processes at Deep Sea Drilling Project/Ocean Drilling Program site 504. J. Geophys. Res., 99:3097-3123.

Fisher, A.T., Becker, K., Narasimhan, T.N., Langseth, M.G., and Mottl, M.J., 1990. Passive, off-axis convection through the southern flank of the Costa Rica rift. J. Geophys. Res., 95:9343-9370.

Fox, P.J., Schreiber, E., and Peterson, J.J., 1973. The geology of the oceanic crust: compressional wave velocities of oceanic rocks. J. Geophys. Res. 78:5155-5172.

Francheteau, J., Armijo, R., Cheminée, J.L., Hekinian, R., Lonsdale, P.F. and Blum, N., 1990. 1 Ma East Pacific Rise oceanic crust and uppermost mantle exposed by rifting in Hess Deep (equatorial Pacific Ocean). Earth Planet. Sci. Lett., 101:281-295.

Friedrichsen, H., 1985. Strontium, oxygen, and hydrogen isotope studies on primary and secondary minerals in basalts from the Costa Rica Rift, Deep Sea Drilling Project Hole 504B, Leg 83. In Anderson, R.N., Honnorez, J., Becker, K., et al., Init. Repts. DSDP, 83: Washington (U.S. Govt. Printing Office), 289-295.

Gillis, K.M., and Robinson, P.T., 1990. Patterns and processes of alteration in the lavas and dykes of the Troodos Ophiolite, Cyprus. J. Geophys. Res., 95:21523-21548.

Gillis, K.M., and Thompson, G., 1993. Metabasalts from the Mid-Atlantic Ridge: new insights into hydrothermal systems in slow-spreading crust. Contrib. Mineral. Petrol., 113:502-523.

Harper, G.D., Bowman, J.R., and Kuhns, R.J., 1988. A field, chemical, and stable isotope study of subseafloor metamorphism of the Josephine Ophiolite, California-Oregon. J. Geophys. Res., 93:4625-4656.

Hart, S.R., Blusztajn, J., Dick, H.J.B., and Lawrence, J.R., 1994. Fluid circulation in the oceanic crust: contrast between volcanic and plutonic regimes. J. Geophys. Res., 99:3163-3174.

Hart, S.R., and Mottl, M.J., 1983. Alkali and Sr isotope geochemistry of waters collected from basaltic basement, Deep Sea Drilling Project Site 504B, Costa Rica Rift. In Cann, J.R., Langseth, M.G., Honnorez, J., Von Herzen, R.P., White, S.M., et al., Init. Repts. DSDP, 69: Washington (U.S. Govt. Printing Office), 487-494.

Hey, R., Johnson, G.L., and Lowrie, A., 1977. Recent plate motions in the Galapagos area. Geol. Soc. Am. Bull., 88:1385-1403.

Hobart, M.A., Langseth, M.G., and Anderson, R.N., 1985. A geothermal and geophysical survey on the south flank of the Costa Rica Rift: Sites 504 and 505. In Anderson, R.N., Honnorez, J., Becker, K., et al., Init. Repts. DSDP, 83: Washington (U.S. Govt. Printing Office), 379-404.

Honnorez, J., Alt, J.C., Honnorez-Guerstein, B.-M., Laverne, C., Muehlenbachs, K., Ruiz, J., and Saltzman, E., 1985. Stockwork-like sulfide mineralization in young oceanic crust: Deep Sea Drilling Project Hole 504B. In Anderson, R.N., Honnorez, J., Becker, K., et al., Init. Repts. DSDP, 83: Washington (U.S. Govt. Printing Office), 263-282.

Honnorez, J., Laverne, C., Hubberten, H.-W., Emmermann, R., and Muehlenbachs, K., 1983. Alteration processes in Layer 2 basalts from Deep Sea Drilling Project Hole 504B, Costa Rica Rift. In Cann, J.R., Langseth, M.G., Honnorez, J., Von Herzen, R.P., White, S.M., et al., Init. Repts. DSDP, 69: Washington (U.S. Govt. Printing Office), 509-546.

Hubberten, H.-W., 1983. Sulfur content and sulfur isotopes of basalts from the Costa Rica Rift (Hole 504B, Deep Sea Drilling Project Legs 69 and 70). In Cann, J.R., Langseth, M.G., Honnorez, J., Von Herzen, R.P., White, S.M., et al., Init. Repts. DSDP, 69: Washington (U.S. Govt. Printing Office), 629-635.

Humphris, S.E., and Thompson, G., 1978. Hydrothermal alteration of oceanic basalts by seawater. Geochim. Cosmochim. Acta, 42:107-125.
Ishikawa, T., and Nakamura, E., 1992. Boron isotope geochemistry of the oceanic crust from DSDP/ODP Hole 504B. Geochim. Cosmochim. Acta, 56:1633-1639.

Ishizuka, H., 1989. Mineral paragenesis of altered basalts from Hole 504B, ODP Leg 111. In Becker, K., Sakai, H., et al., Proc. ODP, Sci. Results, 111: College Station, TX (Ocean Drilling Program), 61-76.

Iturrino, G.J., Christensen, N.I., Becker, K., Bodreel, L.O., Harvey, P.K.H., and Pezard, P., 1995. Physical properties and elastic constants of upper crustal rocks from core-log measurements in Hole 504B. In Erzinger, J., Becker, K., Dick, H.J.B., and Stokking, L.B. (Eds.), Proc. ODP, Sci. Results, 137/140: College Station, TX (Ocean Drilling Program), 273292.

Kawahata, H., Kusakabe, M., and Kikuchi, Y., 1987. Strontium, oxygen and hydrogen isotope geochemistry of hydrothermally altered and weathered rocks in DSDP Hole 504B, Costa Rica Rift. Earth Planet. Sci. Lett., 85:343-355.

Kempton, P.D., 1985. An interpretation of contrasting nucleation and growth histories from the petrographic analysis of pillow and dike chilled margins, Hole 504B, Deep Sea Drilling Project, Leg 83. In Anderson, R.N. Honnorez, J., Becker, K., et al., Init. Repts. DSDP, 83: Washington (U.S. Govt. Printing Office), 165-181.

Kempton, P.D., Autio, L.K., Rhodes, J.M., Holdaway, M.J., Dungan, M.A., and Johnson, P., 1985. Petrology of basalts from Hole 504B, Deep Sea Drilling Project, Leg 83. In Anderson, R.N., Honnorez, J., Becker, K., et al., Init. Repts. DSDP, 83: Washington (U.S. Govt. Printing Office), 129164.

Kinoshita, H., Furuta, T., and Pariso, J., 1989. Downhole magnetic field measurements and paleomagnetism, Hole 504B, Costa Rica Ridge. In Becker, K., Sakai, H., et al., Proc. ODP, Sci. Results, 111: College Station, TX (Ocean Drilling Program), 147-156.

Kusakabe, M., Shibata, T., Yamamoto, M., Mayeda, S., Kagami, H., Honma, H., Masuda, H., and Sakai, H., 1989. Petrology and isotope characteristics $(\mathrm{H}, \mathrm{O}, \mathrm{S}, \mathrm{Sr}$, and $\mathrm{Nd})$ of basalts from Ocean Drilling Program Hole 504B, Leg 111, Costa Rica Rift. In Becker, K., Sakai, H., et al., Proc. ODP, Sci. Results, 111: College Station, TX (Ocean Drilling Program), $47-60$.

Langseth, M.G., Cann, J.R., Natland, J.H., and Hobart, M., 1983. Geothermal phenomena at the Costa Rica Rift: background and objectives for drilling at Deep Sea Drilling Project Sites 501, 504, and 505. In Cann, J.R., Langseth, M.G., Honnorez, J., Von Herzen, R.P., White, S.M., et al., Init. Repts. DSDP, 69: Washington (U.S. Govt. Printing Office), 529.

Langseth, M.G., Mottl, M.J., Hobart, M.A., and Fisher, A., 1988. The distribution of geothermal and geochemical gradients near Site 501/504: implications for hydrothermal circulation in the oceanic crust. In Becker, K., Sakai, H., et al., Proc. ODP, Init. Repts., 111: College Station, TX (Ocean Drilling Program), 23-32.

Laverne, C., 1987a. Les altérations des basaltes en domaine océanique: minéralogie, pétrologie et géochimie d'un système hydrothermal: le puits 504B, Pacifique oriental [Thèse]. Univ. Aix-Marseille III.

, 1987b. Unusual occurrence of aegirine-augite, fassaite and melanite in oceanic basalts (DSDP Hole 504B). Lithos, 20:135-151.

Laverne, C., Vanko, D.A., Tartarotti, P., and Alt, J.C., 1995. Chemistry and geothermometry of secondary minerals from the deep sheeted dike complex, Hole 504B. In Erzinger, J., Becker, K., Dick, H.J.B., and Stokking, L.B. (Eds.), Proc. ODP, Sci. Results, 137/140: College Station. TX (Ocean Drilling Program), 167-190.

Leake, B.E., 1978. Nomenclature of amphiboles. Am. Mineral., 63:10231052.

Leinen, M., Rea, D.K., et al., 1986. Init. Repts. DSDP, 92: Washington (U.S. Govt. Printing Office).

Liou, J.G., Kim, H.S., and Maruyama, S., 1983. Prehnite-epidote equilibria and their petrologic applications. J. Petrol., 24:321-342.

Little, S.A., and Stephen, R.A., 1985. Costa Rica Rift borehole seismic experiment, Deep Sea Drilling Project Hole 504B, Leg 92. In Anderson, R.N., Honnorez, J., et al., Init. Repts. DSDP, 83: Washington (U.S. Govt. Printing Office), 517-528.

Magenheim, A.J., Spivack, A.J., Alt, J.C., Bayhurst, G., Chan, L.-H., Zuleger, E., and Gieskes, J.M., 1995. Borehole fluid chemistry in Hole 504B, Leg 137: formation water or in-situ reaction? In Erzinger, J., Becker, K., Dick, H.J.B., and Stokking, L.B. (Eds.), Proc. ODP, Sci. 
Results, 137/140: College Station, TX (Ocean Drilling Program), 141154.

Mengel, K., and Hoefs, J., 1990. $\mathrm{Li}-\delta^{18} \mathrm{O}-\mathrm{SiO}_{2}$ systematics in volcanic rocks and mafic lower crustal granulite xenoliths. Earth Planet. Sci. Lett., 101:42-53.

Morin, R.H., Newmark, R.L., Barton, C.A., and Anderson, R.N., 1990. State of lithospheric stress and borehole stability at Deep Sea Drilling Project Site 504B, eastern Equatorial Pacific. J. Geophys. Res., 95:9293-9303.

Mottl, M.J., and Gieskes, J.M., 1990. Chemistry of waters sampled from oceanic basement boreholes, 1979-1988. J. Geophys. Res., 95:9327-9342.

Mutter, C.Z., 1992. DSDP Hole 504B: are gabbros in sight? JOI/USSAC Newsl., X:4-6.

Natland, J.H., Adamson, A.C., Laverne, C., Melson, W.G., and O'Hearn, T., 1983. A compositionally nearly steady-state magma chamber at the Costa Rica Rift: evidence from basalt glass and mineral data, Deep Sea Drilling Project Sites 501, 504, and 505. In Cann, J.R., Langseth, M.G., Honnorez, J., Von Herzen, R.P., White, S.M., et al., Init. Repts. DSDP. 69: Washington (U.S. Govt. Printing Office), 811-858.

Nehlig, P., and Juteau, T., 1988. Flow porosities, permeabilities and preliminary data on fluid inclusions and fossil thermal gradients in the crustal sequence of the Sumail ophiolite (Oman). Tectonophysics, 151:199-221.

Nehlig, P., Juteau, T., Bendel, V., and Cotten, J., 1994. The root zone of oceanic hydrothermal systems: constraints from the Samail ophiolite (Oman). J. Geophys. Res., 99:4703-4713.

Nesbitt, B.E., St. Louis, R.M., and Muehlenbachs, K., 1987. Distribution of gold in altered basalts of DSDP Hole 504B. Can. J. Earth Sci., 24:201209.

Newmark, R.L., Anderson, R.N., Moos, D., and Zoback, M.D., 1985. Sonic and ultrasonic logging of Hole 504B and its implications for the structure, porosity, and stress regime of the upper $1 \mathrm{~km}$ of the oceanic crust. $\mathrm{ln}$ Anderson, R.N., Honnorez, J., Becker, K., et al., Init. Repts. DSDP, 83: Washington (U.S. Govt. Printing Office), 479-510.

Noack, Y., Emmermann, R., and Hubberten, H.-W., 1983. Alteration in Site 501 (Leg 68) and Site 504 (Leg 69) basalts: preliminary results. In Cann, J.R., Langseth, M.G., Honnorez, J., Von Herzen, R.P., White, S.M., et al., Init. Repts. DSDP, 69: Washington (U.S. Govt. Printing Office), 497508.

Pariso, J.E., and Johnson, H.P., 1991. Alteration processes at Deep Sea Drilling Project/Ocean Drilling Program Hole 504B at the Costa Rica Rift: implications for magnetization of oceanic crust. J. Geophys. Res., 96:11703-11722.

Perfit, M.R., Fornari, D.J., Smith, M.C., Bender, J.F., Langmuir, C.H., and Haymon, R.M., 1994. Small-scale spatial and temporal variations in midocean ridge crest magmatic processes. Geology, 22:375-379.

Pezard, P.A., 1990. Electrical properties of mid-ocean ridge basalt and implications for the structure of the upper oceanic crust in Hole 504B. J. Geophys. Res., 95:9237-9264.

Pezard, P.A., Anderson, R.N., Ryan, W.B.F., Becker, K., Alt, J.C., and Gente, P., 1992. Accretion, structure, and hydrology of intermediate spreading-rate oceanic crust from drillhole experiments and seafloor observations. Mar. Geophys. Res., 14:93-123.

Pflumio, C., 1991. Evidences for polyphased oceanic alteration of the extrusive sequence of the Semail ophiolite from the Salahi Block (Northern Oman). In Peters, T., Nicolas, A., and Coleman, R.J. (Eds.), Ophiolite Genesis and Evolution of the Oceanic Lithosphere: Dordrecht (Kluwer), 313-351.

Richardson, C.J., Cann, J.R., Richards, H.G., and Cowan, J.G., 1987. Metaldepleted root zones of the Troodos ore-forming hydrothermal systems, Cyprus. Earth Planet. Sci. Lett., 84:243-253.
Salisbury, M.H., Christensen, N.I., Becker, K., and Moos, D., 1985. The velocity structure of Layer 2 at Deep Sea Drilling Project Site 504 from logging and laboratory experiments. In Anderson, R.N., Honnorez, J., Becker, K., et al., Init. Repts. DSDP, 83: Washington (U.S. Govt. Printing Office), 529-539.

Schiffman, P., Evarts, P., Williams, R.C., and Pickthorn, W.J., 1991. Hydrothermal metamorphism in oceanic crust from the Coast Range ophiolite of California: fluid-rock interaction in a rifted island arc. In Peters, T., Nicolas, A., and Coleman, R.J. (Eds), Ophiolite Genesis and Evolution of the Oceanic Lithosphere: Dordrecht (Kluwer), 399-426.

Schiffman, P., Smith, B.M., Varga, R.J., and Moores, E.M., 1987. Geometry, conditions, and timing of off-axis hydrothermal metamorphism and oredeposition in the Solea Graben. Nature, 325:423-425.

Seewald, J.S., and Seyfried, W.E., Jr., 1990. The effect of temperature on metal mobility in subseafloor hydrothermal systems: constraints from basalt alteration experiments. Earth Planet. Sci. Lett., 101:388-403,

Seyfried, W.E., and Ding, K., 1993. The effect of redox on the relative solubilities of copper and iron in Cl-bearing aqueous fluids at elevated temperatures and pressures: an experimental study with application to subseafloor hydrothermal systems. Geochim. Cosmochim. Acta, 57: 1905-1918.

Seyfried, W.E., Jr., Ding, K., and Berndt, M.E., 1991. Phase equilibria constraints on the chemistry of hot spring fluids at mid-ocean ridges. Geochim. Cosmochim. Acta, 55:3559-3580.

Shau, Y.H., and Peacor, D.R., 1992. Phyllosilicates in hydrothermally altered basalts from DSDP Hole 504B, Leg 83: a TEM and AEM study. Contrib. Mineral. Petrol., 112:119-133.

Shimizu, H., Mori, K., and Masuda, A., 1989. REE, Ba, and Sr abundances and $\mathrm{Sr}, \mathrm{Nd}$, and $\mathrm{Ce}$ isotopic ratios in Hole 504B basalts, ODP Leg 111, Costa Rica Rift. In Becker, K., Sakai, H., et al., Proc. ODP, Sci. Results, 111: College Station, TX (Ocean Drilling Program), 77-83.

Stein, C.A., and Stein, S., 1994. Constraints on hydrothermal heat flux through the oceanic lithosphere from global heat flow. J. Geophys. Res., 99:3081-3095.

Tartarotti, P., Allerton, S.A., and Laverne, C., 1995. Vein formation mechanisms in the sheeted dike complex from Hole 504B. In Erzinger, J., Becker, K., Dick, H.J.B., and Stokking, L.B. (Eds.), Proc. ODP, Sci. Results, 137/140: College Station, TX (Ocean Drilling Program), 231243.

Umino, S., 1995. Downhole variations in grain size at Hole 504B: implications for rifting episodes at mid-ocean ridges. In Erzinger, J., Becker, K., Dick, H.J.B., and Stokking, L.B. (Eds.), Proc. ODP, Sci. Results, 137/ 140: College Station, TX (Ocean Drilling Program), 19-34.

Zuleger, E., Alt, J.C., and Erzinger, J.A., 1995. Primary and secondary variations in major and trace element geochemistry of the lower sheeted dike complex: Hole 504B, Leg 140. In Erzinger, J., Becker, K., Dick, H.J.B., and Stokking, L.B. (Eds.), Proc. ODP, Sci. Results, 137/140: College Station, TX (Ocean Drilling Program), 65-80.

\author{
Date of initial receipt: 27 February 1995 \\ Date of acceptance: 13 July 1995 \\ Ms 148SR-159
}

